\title{
Who Do You Think
}

\author{
You Are? \\ Constructing and Representing \\ Central Otago identity
}

By

Jamie Bell

\author{
A thesis \\ submitted to Victoria University of Wellington \\ in partial fulfilment \\ of the requirements for the degree of \\ Master of Museum \& Heritage Studies
}

Victoria University of Wellington

2007 


\section{Table of Contents}

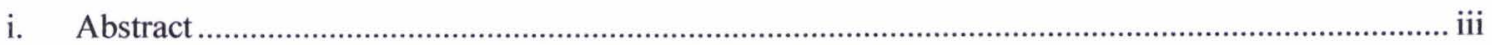

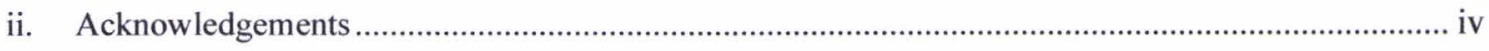

Chapter One

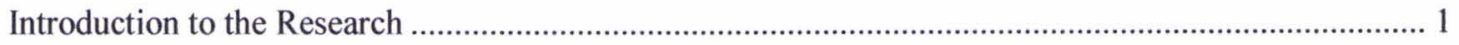

1.1 Background: communicating with communities ................................................................. 1

1.2 Context: regional museums \& regional communities......................................................... 2

1.3 Case Study: Alexandra Museum and Art Gallery ................................................................... 3

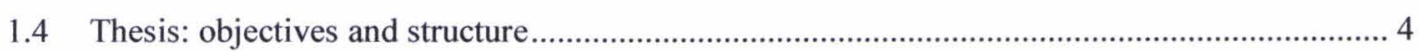

Chapter Two

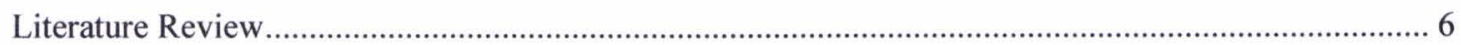

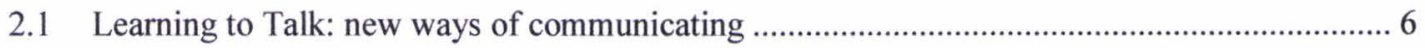

2.2 Making Meaning: the Communicative Circle .................................................................... 8

2.3 Experience and Expertise: frames of reference …........................................................11

2.4 Putting it into Practice: social inclusion .............................................................................. 12

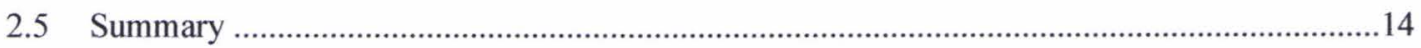

Chapter Three

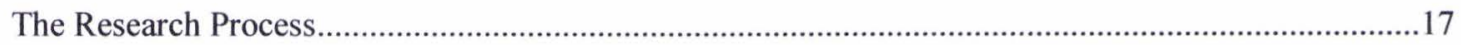

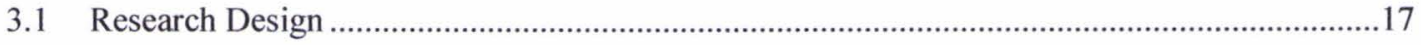

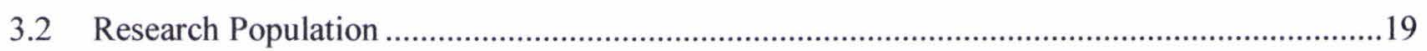

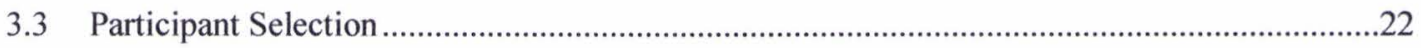

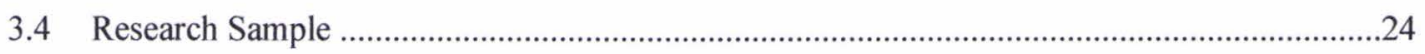

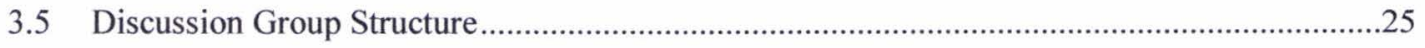

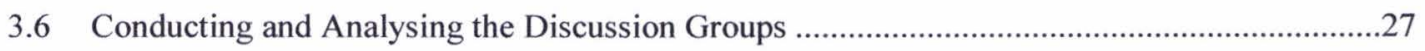

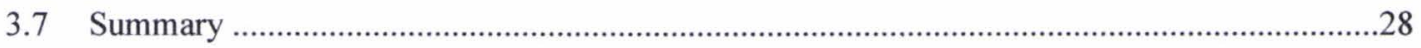

Chapter Four

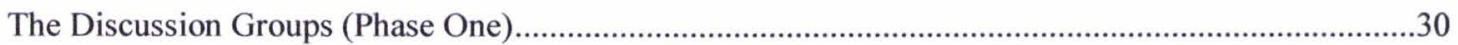

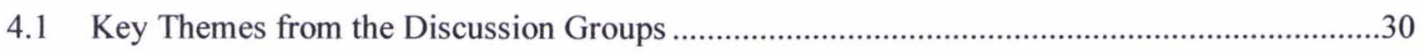

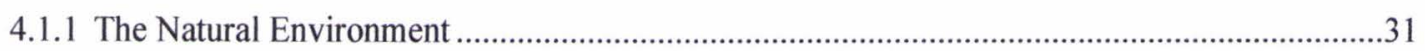

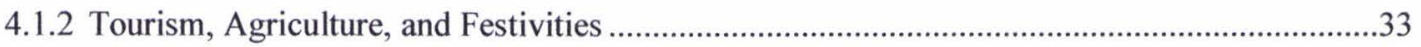

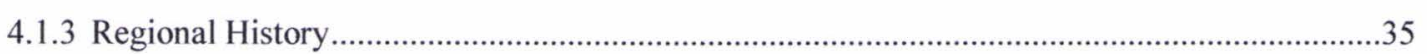

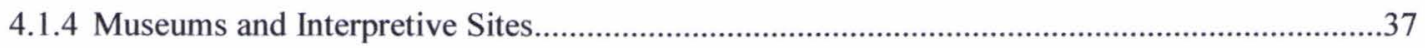

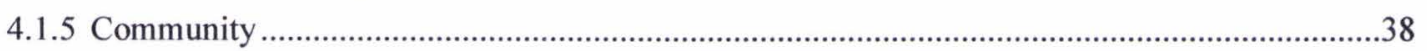

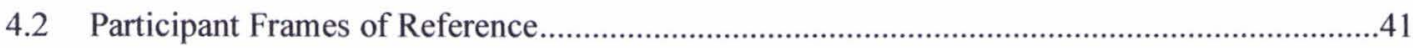

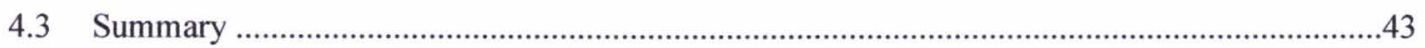

Chapter Five

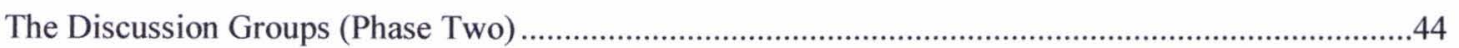

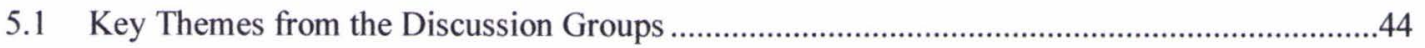

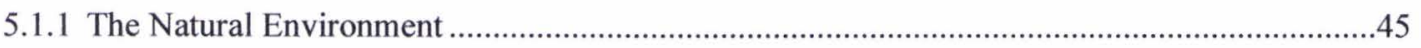

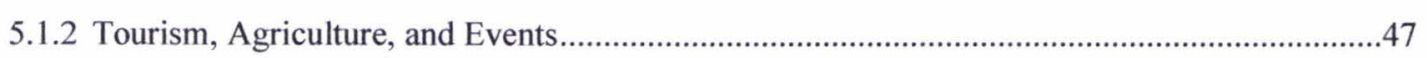

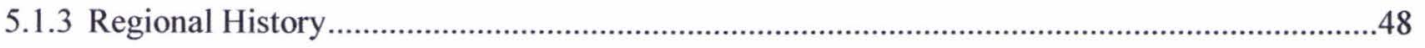

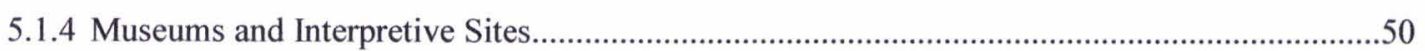


5.1.5 Community.

5.2 Summary.

Chapter Six

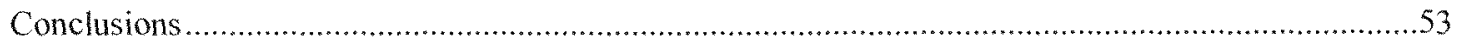

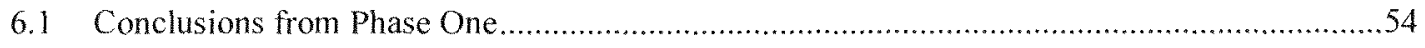

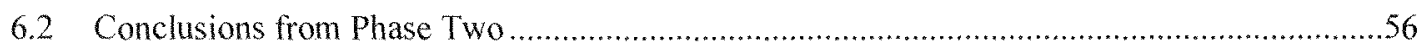

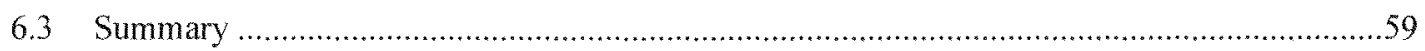

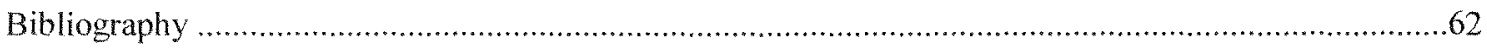

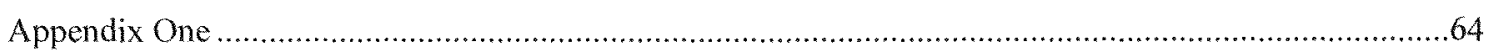




\section{i. Abstract}

As museums are increasingly looking to the local community for support and validation, so too are communities looking to the museum for affirmation of their identity. Theories of meaning making and work in the field of social inclusion have led the way in restructuring the museum into an institution that embraces its surrounding community for the mutual benefit of both sides. In attempting to represent community, museums are taking up these new theories as they build towards becoming ever more relevant institutions. This thesis explores the current literature and investigates its relevance to the museum/community relationship through a case study of the Central Otago community and its new Museum, Central Stories. The study explores the construction of identity within the community and the representation of that identity within the Museum.

In order to investigate the construction of community identity in Central Otago, three discussion groups were conducted in September 2006, with each group made up of members of local community and business groups. The discussions within these groups were divided into two phases, the first of which centred on the construction of Central Otago identity and the second on the Museum's representation of Central Otago identity. In the analysis of these focus groups, common themes were identified surrounding the region's landscape, events, history, museums, and community. In the first phase, participants were particularly reliant on their 'frames of reference' (Perin, 1992) in constructing identity. In particular, the role of personal experience emerged as an important factor in constructing community identity. Comparing the first and second phases of the discussions reveals the complex interweaving of elements in the construction and representation of the community's identity.

The findings of this study highlight the significance of the museum/community relationship in contemporary museology. The developing museological theories on meaning making, particularly those that address the importance of visitor frames of reference, are identified as playing a critical role in developing this relationship. While this study is focused on the Central Otago example, the findings have broader relevance to the field of museum studies through their insights into the dynamics involved in constructing and representing community identity, and the complex relationship between the museum and its community. 


\section{ii. Acknowledgements}

Thanks must firstly go to the community of Central Otago who gave me their encouragement, support, and time. In particular, the people who came along to the discussion groups deserve a special mention. The experiences and insight they shared with me were invaluable to this research.

Special thanks must also go to Lee Davidson. Weeks of silence on my behalf were met with optimism and faith by Lee, whose work in editing, proof-reading, and advising was second to none. She also taught me to appreciate the humble apostrophe.

The Alexandra Museum and Art Gallery gave me full use of their photocopier and meeting room, both of which were gratefully used to the utmost during this study.

Many thanks must go to Tiffany Foskett, who went through this with me as much as anyone else, and to my family; Sally, Graham, and Sarah Bell. Without your support, encouragement, understanding, and nagging (!) I would never have got this done.

Finally, thanks to my Grandparents, who couldn't be here to see this happen, but whose memory inspired it all. 


\section{Chapter One}

\section{Introduction to the Research}

In a letter written around the time the 1800 s became the 1900 s, Samuel Langley voiced the opinions of those the museum had forgotten in its functions. Upon taking on the role of honorary curator of the Children's Room at the Smithsonian Museum, Langley accepted the position by writing a letter explaining the point-of-view of those he had chosen to represent; the children. In his letter Langley described that children have little interest in the Latin names of objects; that they "do not want to have [their] entertainment spoiled by its being made a lesson" (cited in Skramstad, 1996). Over a hundred years later, museums are finding out that it is not just the children who do not want their "entertainment spoiled".

\subsection{Background: communicating with communities}

Museums have undergone radical changes in the last thirty years in an attempt to find their place within a rapidly changing world. This is particularly true in the realm of museum theory, where commentators have been exploring new avenues for the operation and understanding of the museum. While many museums have ignored the challenges they are facing, waving them off with increased visitor numbers, museum theory has wholeheartedly embraced the need for change within the institution. One set of theories that have slowly been adopted by museums are those surrounding museum communication.

In contemporary life the museum sits amongst a multitude of tourist commodities. No longer the authoritative voice of education, the museum is now part of an industry that focuses on the wants, needs, and desires of the visiting public. In order to compete with the high-paced, big money world of tourism, museums are now starting to embrace the type of thinking that Langley placed himself at the centre of. As part of this, much more attention is being paid to in-depth visitor research - beyond numbers and demographics.

Langley's turn of the century observation has become an important realisation for museums 
beyond their relationship to children. Today, museums are finding out that people of all ages do not want a lesson when they enter the museum; they want an experience. It is visitor experience that finds itself at the heart of the new museological focus on communication.

The change to the traditional museum communication model is built on the acceptance that people play a large role in structuring their own museum experience. The old transmission model of communication employed by the museum was based on the one-way flow of 'knowledge' from curator to visitor via object. Modern museums are starting to view the transmission of knowledge as a fatal flaw in their planning; instead the focus is on building a "communicative circle" (Perin, 1992) that fully involves the public in the experience and the construction of meaning.

Projects that seek to implement these changes by involving the community in the museums operational processes are finding out that the benefits extend beyond the museum's walls. Refocusing their attention on the communities that surround them has seen museums effect positive change throughout their community. The first step in implementing these projects is in understanding the people that the museum seeks to serve, and this process is facilitated by visitor research.

Skramstad (1996) wrote of the need for museums to "provide value to society in a way that builds on unique institutional strengths and serves unique community needs". In attempting to achieve this goal, museums are looking more and more to their communities to fulfil their needs; for money, visitors, and particularly, their need for relevance. What current communication models provide is the argument that communities should be looking more towards museums to fulfil their own needs; for entertainment, experience, and particularly, their need to understand their own identity.

\subsection{Context: regional museums \& regional communities}

Prior to New Zealand's 2005 general election, the National, Labour, and New Zealand First political parties all released proposed arts and culture policies that specifically referred to the development of smaller regional museums (National 2005; Labour 2005; NZ First 2005). This focus is reflected in the attempts by New Zealand's leading cultural institutions and organisations to promote the growth of professional standards and practice within these institutions. Among these 
organisations, the Museum of New Zealand Te Papa Tongarewa's National Services Te Paerangi has developed numerous resources centred on regional museums. Their Northland Museums document (Te Papa National Services et al, 2004) exemplifies research being carried out in the field. Likewise, Museums Aotearoa, New Zealand's independent museum organisation, has dedicated much of its 2005 and 2006 national conferences to highlighting the developments happening within these smaller museums.

Despite the helping hand these larger bodies are holding out, it is still a struggle for regional museums to remain professional, focused, and relevant. Where many city museums are able to focus on their place within the tourist market for their revenue, regional museums often struggle with visitor numbers. Without the tourist dollar smaller museums face further challenges for funding; often it is only the support of a local council that keeps them alive. In these circumstances, regional museums need to look towards the local community in order to ensure their survival and demonstrate to funding bodies that they are economically and socially viable institutions.

New perspectives on the museum/community relationship have been developed in an attempt to strengthen ties between the two. This emphasis comes out of the challenge faced by museums to successfully work with their communities in order to represent them in affirmative ways. Recent research has identified the possibility of strong museum/community relationships having a positive effect on community well-being that extends into economic and social areas (HooperGreenhill et al, 2000; Dodd et al, 2001). If regional museums can better understand how communities interpret their surroundings, numerous opportunities for growth and development can, potentially, be created.

\subsection{Case Study: Alexandra Museum and Art Gallery}

In December 2005 the Alexandra Museum and Art Gallery reopened in the new Central Stories complex. Located in the centre of Alexandra, the new complex provides a professional, purposebuilt home for the museum and its collection. With the previous museum closing due to the constant threat of flooding from the Clutha River, an opportunity was provided to develop a modern new museum. Comprising an art gallery that can double as a theatre and education suite, research room, exhibition gallery, storage space, and an Information Centre, Central Stories is a 
comprehensive cultural development.

The Museum collection contains items synonymous with the region's history; from gold mining artefacts to those of fruit growing and wine making. There is also a strong focus on the social history of the region, evidenced with the relocation of the Bendigo Hotel staircase to the new complex. The research room also contains newspapers, books, maps, clippings, and other material that relates to the history of the region. The collection and its associated elements are a major strength of the Museum; the next step is the further development of their display and interpretation.

Alexandra is located in the heart of Central Otago and is famous for its weather, landscape, fruit, and wine. Settled during the gold rush of the 1860s, Central Otago is typical of many of New Zealand's smaller regions in its social and economic output. Central Otago is one of New Zealand's geographically largest regions, yet, with a population of around 17000 people (Statistics New Zealand, 2006), it is one of the least populated. The area has many cultural and historical elements and events through which the community presents itself. From the spring Blossom Festival to the Easter Bunny Shoot, these events are nationally known and recognised - presenting Central Otago to the rest of the country.

In recent years the Otago Central Rail Trail has become a major part of Central Otago's tourist industry. Founded along the former Otago Central Railway, the Rail Trail is a track that is popular with walkers and cyclists. Running from Middlemarch to Clyde, the Rail Trail has reinvigorated many of the small towns that run along the Trail.

Although the Rail Trail is an example of a successful tourist venture within Central Otago, the region offers few other tourist-specific options. While Queenstown is well-known for its tourist attractions, Alexandra relies more on the community immediately surrounding it for its economic well-being. As such, the challenge for the Museum is to present the region in a way that ensures its visitors - the community - see their own identity authentically represented within the exhibits.

\subsection{Thesis: objectives and structure}

This research has two primary aims; firstly, to investigate the construction of Central Otago 
community identity, and secondly to explore the representation of that identity within the Alexandra Museum. From these aims a number of objectives emerge that relate to the case study and its theoretical and practical implications. These objectives are outlined below.

- Explore how the Central Otago community constructs its identity.

- Identify the personal, cultural, and social markers used by the community in constructing Central Otago identity.

- Examine the Central Otago community's response to the Alexandra Museum and Art Gallery's representation of Central Otago identity.

- Investigate the relevance of personal, cultural, and social markers to the community response to the Alexandra Museum and Art Gallery's representation.

These aims and objectives form the basis for the research conducted for my study. In line with this observation, it is important to recognise that other studies have been conducted with comparable aims. Indeed, these other studies can be of great assistance in placing my own research within a larger investigative canon and demonstrating the development of theories concerning museums and their communities. In the next chapter the existing literature that complements the aims and objectives of my study is outlined. 


\section{Chapter Two}

\section{Literature Review}

This chapter introduces the museological theories that have informed the direction of the research conducted for this thesis. Beginning with the changes that have occurred over recent decades regarding the way the museum approaches communication models, the discussion here outlines the theoretical focus on museum/visitor relationships.

The notion that museums have begun to look at alternative ways to communicate with their visitors is illustrated in 2.2 where Perin's (1992) 'Communicative Circle' is outlined and discussed. The communicative circle exemplifies the direction that museums are moving and is important example of meaning making theories. These theories are examined in 2.3 as they provide a link between new models of communication and new ways of addressing the visitor's role in constructing their own experience. Silverman (1995) and Perin's (1992) theories come to the fore as the visitor's role is explored in greater deal through a discussion on the importance of 'frames of reference'.

The theories introduced through the first four sections of this chapter outline the museological background for this research. The chapter rounds out by exploring a more practical approach to investigating these theories by discussing social inclusion work and the benefits such work has seen achieved for both museum and community.

\subsection{Learning to Talk: new ways of communicating}

Much has been made of the changing role of the museum in contemporary society. No longer merely a place for conservation, preservation and research, the external view of the museum has now come to represent tourism, entertainment, and experience. Although museums now need to be viable in a wide range of contexts, many have been slow to react to the shift in their social and cultural position. Theorists have described a stagnant museum profession that has sought the "mythical museum"; anchored in preservation and sophistication, and separated from the everyday world (Hooper-Greenhill, 2000a). With societal changes and the challenge to the 
"mythical museum" ideal, the communicative role of the museum has come into question.

Specifically, there is a call for a "vocabulary of action" within museums (Hooper-Greenhill, 2000a). This vocabulary calls for staff to incorporate the skills of philosophy, learning theories, new museology, and communication theory into their spaces in an attempt to make them more inclusive, alive, and relevant. Where the museum was once seen to dictate its objects and its knowledge to the general public, they are now recognising the value of opening up a dialogue with the community they seek to serve. In the search for new ways to communicate with the visitor, museums are swiftly finding a customer focus that is taking over from the traditional centre on the collection.

Eilean Hooper-Greenhill (2000a, p. 558) simplifies the communicative aims of modernist (traditional) and post-modern (contemporary) museums to two models of communication. The traditional view is based on the transmission model, where the flow of information is one-way, from museum to visitor, and denies any feedback on the part of the visitor. Contrasting this is the model being promoted in post-modern museums. This model is based on the acceptance that learning is a cultural process, built on the personal life experiences of the individual (Dierking \& Falk, 2000).

The transmission model comes from the modernist period when museums were created to reflect the social and scientific values of the period. Museums of the modernist period were organized according to the pervading school of thought of the time; ordered by disciplines (art history, natural science) and by the rules of logic, reasoning, and binary opposites. As such, museums laid information before the public in an authoritarian way; the curator was the informed educator, while visitors were "empty vessels to be filled" (Hooper-Greenhill, 2000b, p. 125).

Westley and MacLean (cited in McQuail, 1987, p. 43) describe this model as being "neutral and purposeless" involving the selection of "what is thought to be of interest to the public". Westley and MacLean's analysis is built on the changes that post-modernist thought has effected on theories of communication within the museum. Within modernist thought the role of communication was purely technical; nothing more than a way to present the dominant discourses of the time to the masses. This is a notable point in the history of the museum's evolution; to these modernist museums, their visitors were an undifferentiated mass, of far less 
importance to the museum than the collection. The biggest change to happen to museums under post-modernism has been the challenging of this notion and the embracing of the visitor.

Hooper-Greenhill (2000b) argues that museums have replaced the transmission model with one that highlights communication as a cultural process. The process of communication is seen as being one that is negotiated and transferred through society, particularly through the interaction between people, culture, and the environment. In this way the 'cultural' model of communication promotes inclusiveness, recognises diversity, and ascribes power to all those involved in the process. Within this theory, the transmission and translation of information from museum to visitor is valued alongside the interpretation and feedback of the visitor; leading to the recognition that visitors are not just an undifferentiated mass.

One of the key elements in the cultural approach to communication is the notion that meaning is made through voice and interpretation, whereas the transmission model's focus was on creating 'truth' in line with modernist thought. The value of the cultural approach in the contemporary world, where traditional models are being contested and broken down, is that it accepts and responds to conflicting perspectives.

There are many aspects of the museum experience that are being reassessed in the wake of the search for new communicative approaches. Dierking and Falk (1997) focus on the physical element in their exploration; determining that exhibition planners can design paths around their exhibits and write text for their objects, but there is no guarantee people will follow their routes or read their words. Likewise, Perin (1992, p. 183) identifies "there is no guarantee that viewers will interpret exhibitions as their makers intend". It is this realisation that has seen museum theorists look towards new methods for involving the public in the processes of the museum.

\subsection{Making Meaning: the Communicative Circle}

Constance Perin's (1992) concept of the 'Communicative Circle' derives from museums attempting to gather feedback from their visitors. This aspect of museum communication was virtually nonexistent under the traditional transmission communication model. However, under the changes that have happened to museological models of communication in the past thirty or so years, museums are placing a greater emphasis on the visitor's viewpoint. 
The communicative circle model is based on the open and continuous flow of information between participants. Unlike previous models, all participants are equal and meaning is created rather than transmitted. Work in the field of social inclusion (explained in detail in 2.5) is one example of the communicative circle in action, although museums are able to place themselves within a communicative circle without going to the lengths that successful social inclusion projects require. Greater visitor involvement in structuring their museum experience is perhaps the most basic way to explain the aim of the communicative circle as a model of museum communication.

Perin (1992, p. 182) determines that the communicative circle is an "ideal", whereby "exhibition makers and viewers cooperate". The notion of cooperation is one that is becoming increasingly evident in relationships between museums and communities, particularly in regard to the mutual benefits each side can gather from their working together. Recent studies have begun to show the evidence of this in cases where museums working with communities have seen benefits across the board for all involved (Matarasso, 1997).

While museums have taken on greater levels of visitor research as their focus has shifted, many are still looking at visitor numbers and demographics to measure their success. It is positive for the future of museums that the role of the visitor has been recognised, however basic visitor research is only the first step in filling the gaps in the communicative circle. Perin (1992, p. 188) identifies that, as members of the museum's communicative circle, it is more important to identify visitors by their "frames of reference" than it is to view their "experiences by socioeconomic criteria". This observation specifically highlights where the value in the communicative circle concept lies, and exemplifies where the failings are in its current implementation.

The structure of Perin's (1992) research followed a similar format to that followed here; an analysis of visitor frames of reference in regards to a specific topic. As such, the outcomes from Perin's (1992) research are pertinent in constructing the theoretical base for my own research. One observation to come from an analysis of the communicative circle is that there is presently little known about "how visitors process their reception", whether it be "on-site or later, alone or in discussions" (Perin, 1992, p. 188). Research, such as that conducted by Perin (1992) and myself, is beginning to look at the ways visitors process their reception by investigating how meaning and knowledge are constructed. 
Through her analysis, Perin (1992, p. 191) determines that the process used to make sense of museums and their objects are "grounded in the ways we make sense of the world". As such, museums need to be aware of how their visitors construct meaning in the everyday world, in order to understand how meaning is constructed within the museum's walls. This is where the notion of the visitor's 'frame of reference' can become a key piece in solving the interpretive puzzle. As Perin (1992, p. 192) herself noted;

As they [audiences] craft meanings and reconstruct knowledge they employ repertoires of collective and personal symbols and experience.

This observation is important for museums to understand if they wish to bridge the gaps in their communicative circle, thus creating a museum that lives up to modern expectations for it to be a vibrant, relevant, and vital institution.

As a new approach to museum communication, the communicative circle is just one example of the developing theories of meaning making. Meaning making is a broad term relating to the theories of museum communication that give increased recognition to the visitor and the role they play in structuring their own museum experience. Where previous communication theories were centred on the transmission of information from museum to visitor, those of meaning making seek to investigate the effect the visitor's own background and experience has on the way they construct meaning within the museum. While visitor experience is the main focus of meaning making, theories have also addressed visitor research, education, and exhibition design (Matarasso, 1997; Guetzkow, 2002; Dierking and Falk, 2000).

The broad scope of meaning making theories have seen research into their influence increase, although, as Rounds (1999, p. 5) notes;

[...] at this stage of development the concept [of meaning making] is more an assemblage of intriguing ideas and provocative experiments than a coherent and comprehensive theory with clear implications for practice.

Rounds (1999, p. 5) introduces meaning making as a theory that has the potential to lead to "a radical new approach to exhibits". In spite of the optimism inherent within this statement, Rounds (1999), like Perin (1992) before him, is quick to realise that much work needs to be done in order 
for the theories of meaning making to have a comprehensive impact.

One element that is key to the establishment of meaning making theories is the recognition that meaning is constructed, not simply transferred. This is what Perin (1992) was referring to when she focused on visitor frames of reference within her research. The challenge for meaning making theorists is to build on the "assemblage of intriguing ideas" and establish an understanding of the tools implemented by visitors in constructing meaning. Rounds $(1999$, p. 7) noted that, to achieve this understanding, meaning making theories will need to address the complex "interplay of cultural and individual elements in this process".

\subsection{Experience and Expertise: frames of reference}

The role of these cultural and individual elements cannot be passed over in attempting to understand visitor meaning making. In reinforcing the importance of these elements, Perin (1992) places emphasis on the visitor's 'frame of reference'. These are the experiences, knowledge, opinions, and ideas that each visitor refers to in the process of interpreting exhibits. While these are intangible and vary from person to person, Perin (1992) recognises their importance in attempting to determine how visitors interpret and construct their museum experience.

Silverman $(1995$, p. 162) breaks the aspects of human experience that most affect the museum experience into three parts: expectations and norms; special knowledge; and life events and situations. Silverman's (1995) final two aspects of experience are the most relevant to both meaning making and the aims of this research. These aspects are important to understand as they provide the basis for a visitor's frame of reference.

While these aspects of experience are unique to the individual, group experience forms a large part of the equation - particularly in regards to community identity. As such, these experiences, events, and situations, are aspects that define an individual, at the same time as tying them to groups. All of these aspects collide within the community, and within any representation of that community, to create a sense of identity that is aligned with a sense of group belonging. As Perin (1992) identifies, understanding these experiential aspects, or frames of reference, provides a starting point from which museums can work towards becoming more relevant to their visitors. 
Bearing in mind the role that group membership plays in the construction of identity, part of the community-based challenge for museums is in their representation of place and community. Silverman $(1995$, p. 162) identifies that visitors bring two aspects of identity to the museum experience; "who I am as an individual" and "who I am as a group member". This second element is the focus of my research, the aim being to investigate how community identity is constructed within the Central Otago community and how this 'frame of reference' impacts on visitor experience, particularly interpretation, within the museum environment. However, it is important to recognise that individual experience also colours identity construction. As Silverman (1995, p. 162) notes, meaning is made through a "constant process of remembering and connecting". Attempting to understand this process is at the heart of meaning making theories, and the research conducted here.

\subsection{Putting it into Practice: social inclusion}

Part of the renewed museological focus on the visitor has seen museums increasingly focus on their relationship with the community surrounding their institution. Recognising that there has always been a relationship between the museum and the community is important in analysing where that relationship sits today. This point is reiterated by Kreamer (1992, p. 367), who notes that:

[T] he history of museum representations of communities and museum activities is an important element in current relations between museums and communities.

One area where the museum/community focus can be evidenced is in theories of social inclusion. These theories build on the importance of the community to the museum and the importance of the museum to the community. More specifically, social inclusion work looks at the processes for, and effects achieved from, including at-risk or minority groups within the museum. Often this is as simple as inviting these groups to visit the museum, however, many museums are addressing the idea of social inclusion in more encompassing ways. The Research Centre for Museums and Galleries (RCMG) at Leicester University has been an active force in social inclusion research and its implications for museum practice. Specifically, the RCMG has produced two documents that go deeper into looking at the community effects achieved by museums that have incorporated social inclusion into their operational vocabulary (Hooper-Greenhill et al, 2000; Dodd et al, 2001). 
The first RCMG document (Hooper-Greenhill et al, 2000) focuses its attention on larger institutions and their attempts at social inclusion. Many of the museums included within the research specifically mention the importance of community and community relationships to their museums (Hooper-Greenhill et al, 2000). Recognising these partnerships and links highlights the way in which museums are moving in associating themselves with their communities in mutually beneficial ways.

The latter RCMG research investigated social inclusion within small museums (Dodd et al, 2001). As an emerging concept, social inclusion is recognised as a fluid and developing term. However, within the RCMG report (Dodd et al, 2001) the result of social inclusion work is described as "the positive impact that museums can have on the lives of those groups and individuals with which they engage". While this statement is broad in its description of those involved in social inclusion, the RCMG research (Dodd et al, 2001) is focused on at-risk and minority groups. The above definition does however highlight that the effects, ideas, and outcomes of social inclusion work can relate to museum and community relationships on a broader scale. Research like this begins to identify the ways in which museums can aid in building stronger communities by including them in the practices of the museum.

In spite of the focus on at-risk and excluded groups, these RCMG documents (Hooper-Greenhill et al, 2000; Dodd et al, 2001) identify how the theory behind social inclusion is seeing many museums expand their mission statements to focus on positive societal impact on a communitywide scale. This is exemplified in the mission statement of the Tyne and Wear Museum, which aims to "help people determine their place in the world, and understand their identities, so enhancing their self-respect and their respect for others" (Hooper-Greenhill et al, 2000, p. 12). This idea indicates the way in which museums are moving to further embrace their communities and highlights the goals they are seeking to achieve.

My study builds on the notion that museums can have a positive impact on the community beyond the walls of the institution. In particular, the focus here was on the notion of community identity and its construction within the community and representation within the Alexandra Museum. Kreamer (1992, p. 371) tied together the two central elements of positive impact and identity when she stated that "communities often look to museums as places in which identity is 
articulated". The recognition in this statement, as it is in this thesis, is that the museum is an important place for the construction of identity.

The question that these social inclusion studies leave us with is what constitutes community? Incorporating at-risk groups within the museum can only be done when the community is defined. The same is true in attempting to explore the notion of community identity. In his overview of arts impact studies, Guetzkow $(2002$, p. 14) identifies that community can be defined in two ways: "propinquity and group membership". In terms of the first way of defining group membership, geography has played a large role in this definition. Researchers in the field of geography have spent a great deal of time examining the definition and construction of place within their field (Paasi, 1986; Johnston, 1991). More telling than the geographical definition of community is the notion of group membership. Certainly, it is this element that social inclusion studies focus their attention when looking to the community. Guetzkow $(2002$, p. 15) recognises that it is of great importance to distinguish between "researcher-imposed" and "self-identified definitions of identity". This notion is taken up in the study conducted here, where the self-imposed definition of Central Otago community identity is the focus of the exploration.

\subsection{Summary}

Museums have established a long history as authoritative institutions where the wonders of the world are on display, ready to be understood by the masses who visit. Over the last hundred years the notion of the museum as authoritative and above the everyday has been slowly eroding. With museums now sitting firmly within the tourism industry they have had to approach their operations with a new view that centres on the visitor instead of the collection. This does not mean museums need to downgrade their tasks to that of the amusement park; instead they have re-evaluated their approach to communicating the meaning of objects.

This re-evaluation has seen museums move away from the traditional transmission model of communication towards one that embraces learning and the construction of meaning as a cultural process. Under the transmission model, the understanding and knowledge of the curator was passed on to the visitor with little acknowledgement given to the visitor's role in the museum experience. The assertion that the construction of meaning is a cultural process, based on previous experiences, is one that opens the museum up to more inclusive and relevant operations. 
Part of the change to the way museums approach communication comes from the need to understand how the visitor interprets their own experience. Many museums take this notion on board through their visitor research programmes; although the time and money associated with these means they are not always as productive as they might be. Perin (1993) offers the 'communicative circle' as an answer to both research needs and models of communication. The communicative circle offers a new model of communication where the flow of information is continual and reciprocated between museum and visitor. This model allows visitors a greater role in their own museum experience, while opening museums up to their visitors on an even greater scale.

The communicative circle provides an example of a developing theory of meaning making. These theories highlight the shift the museum is making towards recognizing the role of the visitor. Meaning making theories address the cultural elements that the new museum communication models are moving towards. As part of this, the basis of meaning making theory lies in the recognition that the construction of meaning within the museum is not an isolated event. Instead, it is centred in the everyday life of the visitor; their experiences and knowledge of the world shapes their interpretation of the museum world.

Perin (1992) identifies these experiences as 'frames of reference'; the elements that visitors refer to in their interpretation of the museum. These aspects of experience are identified by Silverman (1995) as falling into three categories; the two most important to this research being special knowledge, and life events and situations. These aspects are a vital part of understanding how visitors construct meaning within the museum by referring back to other aspects of their lives.

These theories of meaning making are part of an approach by the museum profession towards involving the visitor in the museum to a greater extent. While part of this is due to enforced changes necessitated by the shift in the museums place within society, part of it also due to positive effects being achieved through museum/community projects. Social inclusion work in particular has shown that museums can have an extremely positive impact on their community through working with them and involving them to a greater extent within the museum. The effects seen by social inclusion projects often directly impact on notions of community identity and pride (Matarasso, 1997). However, in order to see these effects, museums first need to 
understand the dynamic between the construction of meaning and visitor frames of reference.

The studies briefly explored through this literature review highlight the direction in which museums are moving towards more inclusive models of communication. In particular, it is the need to further involve the visitor in the processes of the museum for the mutual benefit of both sides that is being sought. Theorists are attempting to come to grips with how visitors construct meaning in order to achieve these positive results. Rounds $(1999$, p. 5) noted that meaning making theories are just "an assemblage of interesting ideas" at this stage in their development. This research further examines the processes of meaning making by investigating how visitor frames of reference impact upon their construction of meaning within the museum. 


\section{Chapter Three}

\section{The Research Process}

Museum visitor research is becoming increasingly recognised as an important ingredient within successful museums. It is only within recent years that concerted attention has been paid to the place of the visitor as an active participant within the museum. As such the field of visitor studies within museums is a developing one.

The development of visitor research methods and approaches has come through steady progress and the dedication of a few theorists (Dierking and Falk, 1997; Dierking and Pollock, 1998;

Crowley, Leinhardt, Knutson, 2002). What has become evident is that every situation is different and standardised procedures are difficult to impose.

This chapter outlines the research process conducted in the investigation of this study's aims and objectives. The methods employed and their strengths and weaknesses are outlined alongside those of other methods to demonstrate the approach taken to this investigation. The research population is also examined with particular attention paid to the selection and demographics of this population. Having determined the research population, issues of participant selection and demographics are then addressed. Finally, this chapter deals with the structure of the selected research method, analysing the reasons behind this structure and any limitations placed on the research as a whole.

\section{Research Design}

Research methods themselves have become the subject of much writing and debate, theorists on one side argue for the use of qualitative methods, while those on the other side relate the virtues of quantitative. The nature of social science research often sees those who seek to investigate it begin their study by selecting a method that belongs to one of these two camps. Where quantitative methods centre on the definitive through numbers, measurement, and answers, qualitative methods seek to explore all the aspects that affect the subject. As Denzin and Lincoln (2003, p. 8) explain, qualitative research seeks "answers to questions that stress how social 
experience is created and given meaning". This focus on the creation of meaning reflects many of the meaning making concepts introduced in Chapter Two. As such, qualitative methods offer the greatest opportunity to explore Central Otago community identity.

Concluding that qualitative methods offer the appropriate type of enquiry into this topic is only the first step in designing the research for this study. In deciding on which of the many types of qualitative methods to employ, careful consideration must be given to their strengths and weaknesses in relation to the topic of Central Otago identity. Perhaps the most often used qualitative method is that of the individual interview. Individual interviews involve a one-on-one interaction between the researcher and the participant based on a structured or unstructured question format. This method has many advantages for the researcher; they are able to clarify any misunderstandings easily, the response rate is high, and the interview structure is controlled, amongst other advantages. Many of the advantages of individual interviews are based on their use over methods such as questionnaire forms that participants fill in themselves. The individual interview also has limitations, including the challenge faced when addressing sensitive issues.

The greatest advantage of the individual interview approach is that a great deal of quality information can be gathered, with the researcher maintaining some degree of control over the entire process. One aspect that needs to be taken into account, however, is the community nature of this study. While individual interviews provide many advantages, they have a major disadvantage in their focus on the views of only one participant. Another method that affords many of the advantages of individual interviews is the discussion group.

Discussion groups are essentially a group interview, allowing participants to collectively interpret, debate, and discuss the topic. The decision to focus on discussion groups in this research is validated by Bryman's (2004, p. 348) assertion that:

The process of coming to terms with [...] social phenomena is not undertaken by individuals in isolation from each other. Instead it is something that occurs in interaction with others.

Allowing participants to interact with each other and discuss the topic of community identity in a group environment creates the opportunity to collect data that better reflects the community as a whole. 
Therefore the major research method employed here is that of discussion groups.

While the discussion group and the individual interview share many of the same benefits, the discussion group offers up some disadvantages of its own. Many of these disadvantages relate directly to the discussion itself; domination by some participants and a lack of participation from others, participants afraid their input will not be accepted by the group, difficulties in keeping the discussion on track. Recognising these issues prior to conducting discussion groups offers the researcher the opportunity to be proactive in their leading of the discussion, an approach that can assist in overcoming these negative aspects.

Enabling more varied, detailed, and contested data to be gathered than other qualitative methods, the discussion group is an ideal method for the investigation of community identity. Outlined in the rest of this chapter are further considerations made in the design and implementation of research for this study.

\subsection{Research Population}

The research population for my study encompassed all Central Otago residents in line with Perin's (1992, p. 188) assertion that:

When visitors are viewed as members of the communicative circle, it is more telling to identify them by the frames of reference that filter their viewing experiences than socioeconomic criteria.

Perin's (1992) concept of the communicative circle was discussed at length in Chapter Two, where it was ascertained that visitor frames of reference are an important aspect in the construction of meaning. As the focus of this study is on the construction of Central Otago community identity, the most important frame of reference is participant experience within the region. Selecting members of Central Otago's usually resident population (identified as 16647people in the 2006 Census $^{1}$ ) as the research population ensured this frame of reference would be present within the study.

Defining Central Otago's geographical boundaries is complex as the region is made up of many

\footnotetext{
${ }^{1}$ All 2006 Census data taken from Regional Data by Territorial Authority document (Statistics New Zealand, 2006).
} 
smaller areas (such as Maniototo and Teviot). Proposed changes to electorates have made defining Central Otago's boundaries more difficult as some towns are being shifted from the Otago electorate to the Southland electorate. Statistics New Zealand provides a geographical definition of Central Otago as part of their Census analysis that encompasses the Teviot district to the east, Cromwell at the western boundary, and the Maniototo region towards the north. Within this area lie the towns of Roxburgh, Alexandra, Clyde, Omakau, Naseby, and Ranfurly. With the difficulties inherent in defining the geographical boundaries of Central Otago it is the region described by Statistics New Zealand (fig 1) that this study takes as its focus.

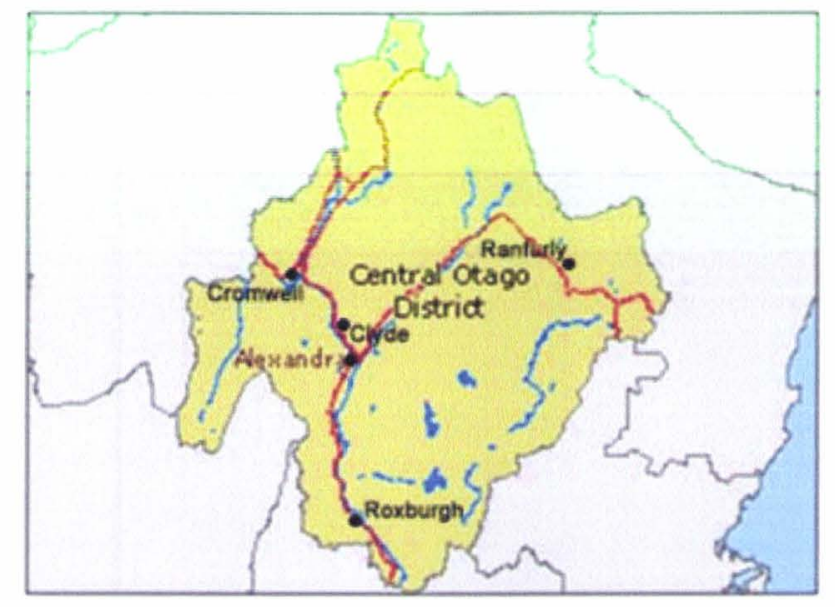

Figure 1; Map of Central Otago District

www.nowwhere.com.au/statsNZ/locator/default.aspx

The data collected by Statistics New Zealand at the 2006 Census provides further statistical information about the Central Otago region. This data, collected in March 2006, identifies the demographic make-up of the Central Otago region - providing further insight into the research population. Between the 2001 and 2006 Censuses the usually resident population of Central Otago rose $15 \%$, identifying a region that has grown significantly over that five-year period.

The demographics of the 16647 people counted in the Central Otago region in March 2006 depict a region that is quite different to the rest of the nation in many respects. This is particularly evident in the ethnic make-up of the region. New Zealand's reputation as an ethnically diverse nation is represented in the 2006 Census data, although the population is dominated by $71.3 \%$ of respondents choosing either "European" or "New Zealander" as their ethnicity. While New Zealander is a fairly ambiguous term, and has only been introduced at the 2006 Census, it was included after an overwhelming number of people in previous Censuses had written "New Zealander" in the "Other Ethnicity" option. The number of people in Central Otago who chose 
either "European" or "New Zealander" as their ethnicity was significantly larger than for the nation as a whole - sitting at $91.5 \%$. To further exemplify the ethnic variation between Central Otago and New Zealand: $6.7 \%$ of Central Otago residents noted their ethnicity as "Maori", compared to $13.3 \%$ for New Zealand.

Age is another demographic where some variations can be seen between Central Otago's numbers and those of the nation as a whole. While Statistics New Zealand breaks age down into five year brackets, I have collated the data into larger segments to represent four demographic variables. Within New Zealand, the 0-19 years age group is the largest, representing $29 \%$ of the total population. The next highest groups are 20-39 and 40-59 which both present $27 \%$. The age group with the lowest percentage is the 60 plus group, rating at only $17 \%$ of New Zealand's usually resident population. Within Central Otago this 60 plus age group represents a much higher proportion of the population at 24\%, while the 40-59 age group make up a third of the region's total population.

Aside from the differences in ethnicity and age, Central Otago is quite representative of the rest of the nation in other areas. One of these is gender, where Central Otago is virtually 50/50 between males (49.9\%) and females (50.1\%). The statistics for the entire nation see females at $51.2 \%$ and males $48.8 \%$, a difference that is only marginal to the Central Otago statistics.

My study centred on collecting data around a highly debatable aspect; as such the number of participants was kept relatively low. This negates any attempt to gain a statistically representative sample of the research population. In spite of this, some attempt was made to make the sample as representative as possible. It was felt this was necessary to the research, as the level of impact that demographic characteristics may have on identity construction could not be assumed before hand.

Data from Statistics New Zealand provides a portrait of the Central Otago region in terms of geography and demographics. This data is able to provide an interesting contrast to the definitions imposed on the region by the community itself. 


\subsection{Participant Selection}

It has already been established that the primary defining characteristic of participants in this research was that they were a Central Otago resident. In order to gain participants who reside within the Central Otago region, six community groups and business groups were approached to provide participants. By selecting participants who have made a commitment to a community group it was anticipated that they would all be permanent residents of the area.

Each of the community and business groups approached was asked to provide three participants so that one member from each would be present in the three discussion groups. While these community and business groups were approached first by mail and then in person, the level of interest was not as high as anticipated. As such, the number of community and business groups approached was expanded to include three further groups, and the number of participants each provided was reduced to two. This reduced the repetitiveness of having participants with similar backgrounds in each discussion group, and allowed a greater range of community voices to be heard.

Lavenda (1992) identified the dangers in assuming that the voice of a community is a unitary one, highlighting how the voice of certain sectors of the community can become louder than others. The choice of which community groups to include in the research was made with this in mind; as such, the initial six groups were chosen to represent a broad section of the community and to provide a range of demographic variables. Through my own experience with the Central Otago region, and by researching the community notices in the Central Otago News and Mirror newspapers, I decided upon six groups that represented Central Otago in ways that cross over sporting, cultural, economic, and demographic factors. The initial community and business groups approached were:

- Clyde Promotions Group

The Clyde Promotions Group is made up of volunteers from around the Clyde, Earnscleugh, Springvale and Alexandra areas. It is responsible for many events and activities throughout the year. Membership is a mix of genders, with most members aged 40-60. 
- Earnscleugh/Manuherikia Community Board

The members of the Earnscleugh/Manuherikia Community Board are voted onto the board at the time of regional elections. The Board serves as a feeder to the Central Otago District Council and works with both the Council and the Community to provide services throughout the region. Members are primarily a mix of genders and are middle-aged.

- Terrace Primary School Staff

The Terrace Primary School is one of the largest primary schools in the Central Otago area. While it is located in Alexandra, the staff comes from throughout the region. While the staff is primarily female, the Terrace Primary School has many male teachers and a relatively young staff.

- Central Otago Education Centre Staff

The Central Otago Education Centre works with many groups aside from schools throughout the area; providing resources, venues, and workshops. The staff of the Education Centre is predominantly female, although many people are associated with the Centre daily.

- Dunstan High School pupils

Dunstan High School is the main high school in the area (Cromwell College and area schools in the Maniototo and Roxburgh the only other schools that cater to high school-age children). As such, pupils come from across the region - with many boarding at the School's Hostel.

\section{- Alexandra Soccer Club}

The Alexandra Soccer Club is one of many sporting groups within Central Otago. The Club takes in members ranging from 5 years through to supporters and committee members in their 60 s. While the club is predominantly male, there are a number of younger female players and female supporters.

These six groups provided the basis for the three discussion groups run in order to collect the data for this study. Twelve of the total eighteen participants came from these initial groups, with the final six participants coming from the three further groups approached: 
- Central Otago Four-Wheel Drive Club

The Central Otago Four-Wheel Drive Club is particularly active within the community, often opening their events up to the general public and organising fundraising events for other groups. The members of the Four-Wheel Drive Club are predominantly in an older demographic with membership often consisting of both husband and wife.

- Alexandra Paper Plus

Alexandra Paper Plus is a locally owned and operated store in the Paper Plus chain. It is one of the busiest shops in Alexandra and has a small staff that comes from a variety of demographic groups.

- Dunstan Hospital Staff

Located in Clyde, the Dunstan Hospital is the Central Otago region's largest healthcare facility. Recently renovated, the Hospital employs a large number of staff from throughout the Otago area. Staff at the hospital are from a range of age groups with many other demographic variables.

From these nine groups the 18 participants for this study were found. The research sample is examined in more detail in the next section.

\subsection{Research Sample}

As detailed in the previous section, this study involved 18 participants from a variety of business and community groups within the Central Otago community. These 18 participants were involved in the three discussion groups (six in each group) conducted on the $15^{\text {th }}$ and $16^{\text {th }}$ of September 2006.

It has already been established that participants were primarily chosen on their being a Central Otago resident. Demographic factors in the selection of participants were passed over in favour of selecting participants whose frame of reference included the experience of residing in Central Otago. However, amongst the factors that were anticipated to have a bearing on this frame of reference, gender and age were considered to be two of the more important. As such, some effort was made to gather participants who broadly covered these demographics. 
The research sample was made up of $56 \%$ females and $44 \%$ males, reflecting the slight female domination in the 2006 Census data. Additionally $50 \%$ of participants were within the $40-59$ age group as a reflection of Central Otago's slight over-representation in this area. Participants ranged in age from 14 to "70-something", providing an overall range of perspectives on the basis of age alone. While both these demographic elements were anticipated to have some bearing on the nature of responses, gender proved to be less influential than age.

Likewise, it was anticipated that the length of time spent in the area would have some bearing on participant construction of Central Otago identity. Again, in the recruitment of participants, some effort was made to encompass people who had lived in the region for a range of time-periods. This further added to gathering a broad range of views from as broad a cross-section of the community as the limitations of qualitative research allow, with the greatest opportunity to see the benefits of qualitative research.

The research methods, selection of participants, and make-up of the research sample were all aspects that influenced the structure of the discussion groups. Having discussed these elements in the previous sections, the next section deals with the structure of the discussion groups and how these other elements influenced the format of the discussions.

\subsection{Discussion Group Structure}

There are many aspects to take into account when structuring discussion groups. From the issues already outlined surrounding participant selection to questions of group size and the discussion outline, these aspects are vital in ensuring discussion groups are run in the most productive way.

Regarding the number of people in each discussion group, Morgan (cited in Bryman, 2004, p. 351) recommends that groups should be smaller in size for topics that are likely to stimulate greater discussion. Community identity is certainly such a subject, especially considering the difficulties inherent in expressing a unified identity. Morgan's recommendation however only gives an indication as to what size groups should be. Indeed, there is no rule as to the ideal number of people to include within a discussion group. While some theorists recommend group numbers of eight to ten people (Macnaghten and Jacobs cited in Bryman, 2004, p. 350), it is difficult to impose 
standards on this area of structure as each study is different and requires different methods. As mentioned earlier, the discussion groups conducted for my study featured six participants in each group. This number reflected an intention to keep the tone of the discussion conversational and the amount of data collected at a manageable level.

Further reflecting the need to keep the amount of data collected at a manageable level, without compromising its validity, three discussion groups were conducted. Bryman (2004) notes that researchers should seek to run discussion groups until they can realistically predict the responses of further groups. In theory this aim is admirable, unfortunately the time and data restraints on my study made this impossible. In spite of this, I feel that had I run a fourth group, I would have been able to predict many of the responses in line with Bryman's recommendation.

This study was set out with dual aims, the first focusing on the construction of identity while the second centred on the representation of that identity. Because of this, the discussion groups were structured to mirror and explore these aims. Each discussion group was divided into two phases, each one reflecting the dual aims of the research.

The questions in each phase were similar, albeit with the focus shifted, so as to provide an opportunity to evaluate the findings of each phase in relation to the other. In phase one this focus was on the construction of community identity, with questions focusing specifically on the community role in constructing Central Otago identity. In phase two the emphasis was placed on the museum and its role in the representation of Central Otago identity. During an intermission between the two phases, participants were encouraged to view the Alexandra Museum's exhibitions in preparation for the second phase's shift of focus.

While the discussion format of these groups was planned beforehand, and a series of topics set out for discussion, some latitude was allowed to participants during the discussions. This aspect of structure built on Bryman's (2004, p. 352) assertion that there is the "tendency for moderators to allow quite a lot of latitude to participants", while Dierking and Pollock $(1998$, p. 48) reiterate the positives that can be achieved through doing this. The discussion format is outlined in appendix one, where the comparisons between phase one and phase two can be evidenced. 
One of the most important aspects of discussion group implementation is the recording of data. Ensuring that the discussions are recorded clearly and accurately is vital for the analysis of the information presented. This section outlines the processes taken to ensure the discussion groups conducted for this study were recorded in such a way. Further elements of the analysis of data are also described, including the methods employed in collating and making sense of the information presented. Finally, this section ends by highlighting some of the limitations of the discussion group method that became evident following their implementation.

Sarantakos (2005, p. 198) identifies one of the weaknesses of discussion groups as that the "recording of the data can be problematic". Recognising this prior to conducting discussion groups is important in ensuring all the data presented is recorded for analysis. In this study the groups were video taped so that any physical clues or interactions could be observed. In order to ensure the discussion was recorded clearly, the discussions were also recorded with a tape recorder. This was done particularly to make the process of transcription easier. Throughout each of the discussion groups notes were also taken, highlighting any observations made about the discussion and interaction of the groups.

Following the discussion groups, the tape recordings were transcribed, with any notations from the video tapes added. Analysis of the transcribed groups was done by highlighting key themes in the transcription and making a note of these. After this had been done for each phase of the discussion groups, the themes were analysed in greater detail. This process was completed simultaneously for the data presented in each discussion group.

Having run the discussion groups and analysed the transcriptions, two issues presented themselves as possible limitations to the research. The most notable of these was perhaps the incomplete nature of the Alexandra Museum's exhibition space. At the time the research was conducted, the Museum had only opened approximately one third of its total exhibition space. While it was believed that many of the elements of Central Otago that may be seen as definitive were represented within the existing exhibition, participant responses to the exhibition could often be countered by the fact the exhibition was incomplete. Although this element was out of my control, it is important to note the limitation it imposed on the research. 
Holding the discussion groups within the museum was done so as to provide participants with an opportunity to view the exhibitions. This was an absolute necessity prior to moving into phase two of the discussion. Although it did not specifically show up in participant responses, holding the discussion groups within the Museum may have placed limitations on the first phase of the discussions. This initial phase was centred on the wider Central Otago community, although many questions indirectly addressed the Museum. By holding the discussions within the Alexandra Museum it can be reasonably assumed that this had some bearing on the discussions in this first phase.

Other aspects perhaps affected this research, although most of these were outside of the researcher's control. Issues of timing and time available are always important when conducting research and this project was no different. While these limitations undoubtedly had some impact on the research conducted, the design and methodologies chosen were done so with the utmost care and consideration for all the variables involved.

\section{Summary}

Dierking and Pollock (1998, p. 52) describe the need to create "a sample that will give rich and meaningful information rather than a large, randomly selected sample" when conducting research. With emphasis in research design often put on the value of a large sample size, Dierking and Pollock reinforce the value of having a representative sample. However, the term 'representative sample' is not without its problems: representative of what? The most common answer is representative of the demographics of the research population. Perin (1992, p. 188) offers a more viable answer when she identifies frames of reference as "more telling" to the viewing experience than other criteria.

Much of this study builds on the work of theorists like Perin (1992), who have argued for the role of previous experience and knowledge in structuring the visitor's museum experience. The notion of the visitor's frame of reference is at the forefront of this study's investigation into the construction and representation of community identity. As such, the choice was made to select Central Otago residency as the primary participant characteristic in an attempt to gather "rich and meaningful information" (Dierking \& Pollock, 1998). 
The community-based focus of the research led to the decision to use a research method reflective of the community. Qualitative approaches were identified as providing the best opportunity to gain in-depth and detailed data. This led to the choice of discussion groups as the primary research method.

While the discussion group format offers many challenges to the researcher, it was appropriate to this research in the way it allows participants to interact in an environment that echoes the community-based aims. Individual research methods all come with associated benefits and failings, the challenge is to select a method that is most appropriate to the research at hand. While the discussion groups conducted for this study produced some minor research limitations, they also drew out a great deal of detailed, relevant, and insightful data.

The decisions made in the design of the research for this study were all made with the research aims and objectives at the forefront of my mind. This aspect is echoed in the selection of participants, the research methodology, and the approach taken to analysis. As such, this study has been approached as the most appropriate way to investigate the notions of community identity, its construction and representation. No research project can ever claim to present the 'truth', and this study certainly never set out with this intention. Much like the rationale behind selecting qualitative research, this research has been designed to explore the relationships between the community, their identity, and the museum. 


\section{Chapter Four}

\section{The Discussion Groups (Phase One)}

This chapter discusses the results from phase one of the discussion groups. In order to analyse the data it was necessary to identify key themes that were presented during the discussion groups. These key themes covered the construction of Central Otago identity, reflecting many diverse elements of the region. In this chapter these themes are identified and then described in relation to the discussion groups and their importance to the construction of Central Otago identity.

The discussion outline was divided in to two phases, designed to investigate the creation of community identity within the Central Otago community in the first phase, and then the representation of that identity within the Alexandra Museum during phase two. The first phase of each group featured the same six discussion topics. These topics were designed to cover a range of concepts and ideas relating to Central Otago, identity, and community. The discussions in each group had varied, although the key themes were evident throughout.

\subsection{Key Themes from the Discussion Groups}

In the first phase, the discussion investigated how participants felt about their region; the aspects that made it unique, what made it home, and any other issues that arose. Throughout the discussions there were several themes that appeared on a consistent basis. While the approach to these themes varied from person to person and group to group, the same central themes were evident throughout all the discussion groups.

These five central themes were:

1. The Natural Environment

2. Tourism, Agriculture, and Events

3. Regional History

4. Museums and Interpretive Sites

5. Community 
The emergence of these themes in the first phase of the discussion groups highlights the need to be aware of their importance to the second phase of the discussion. Within these themes lie the significant elements of Central Otago identity as viewed by the people of the region. These themes are explored further here to highlight where they fit into Central Otago's regional identity as it is constructed by the community.

Emerging as a constant throughout each of these themes was the impact that memories and experiences had on the construction of Central Otago identity. These frames of reference play a large role in the community's understanding and construction of identity. This aspect of the discussion is outlined in 4.2.

\subsubsection{The Natural Environment}

The natural environment is a theme that is often focused on in marketing the Central Otago region. From the renowned hot days of summer and freezing days of winter, to artist Grahame Sydney's iconic landscapes, Central Otago has become renowned for many aspects of its natural environment. While it is easy to recognise these from current and previous marketing for the region, it was important not to let these stereotyped ideas inform the expectations for the discussion groups. The benefit of using local people to evaluate the local identity is that they are less affected by the tourism marketing. Indeed, they are in the best position to critique it and set the record straight.

In two of the discussion groups, weather was the first defining aspect mentioned, although it was closely followed by landscape and geology. The third group also mentioned landscape in the early stages of their discussion, although the focus of this group's attention was different to the other groups. In this third group, much of the talk centred on personal experience and broad descriptions of the region's defining aspects. In the other groups the initial discussion often listed key words and images ("thyme", "big skies", "schist", and so on) before delving deeper into an explanation of these aspects.

While weather was often mentioned early in the discussion it was not given much explanation. Indeed, many of the groups seemed to pass over the importance of weather, despite giving it such 
a high profile. In general, weather was mentioned briefly before moving on to talk about other elements of Central Otago. In the latter stages of the discussions, people often described childhood memories that were closely intertwined with the weather and climate. From incredibly hot summer days spent at the Clyde Pool, to winters with no school due to fortnight-long frosts, these memories provided evidence of just how important Central Otago's climate is to its identity and the identities of its inhabitants.

One participant described how they often tell overseas visitors that Central Otago is "a desert really", in contrast to expectations that the climate is temperate with high rainfall. The notion that there are pervading false perceptions and stereotypes of Central Otago became a recurring theme in these discussions. These false perceptions of the region were often seen as having been perpetuated by the media and adopted by people from outside the region.

While Central Otago's temperature extremes played a large part in discussions about the weather and climate, the third discussion group focused their attention more on the region's seasons and the impact they have on Central Otago. This group promoted the idea that the seasons are very important to Central Otago as they dictate many of the local activities, alongside the postcard views they provide. From the distinct colours of autumn and spring, to the change in mood when the winter frosts sweep in, the seasons prompted many emotive responses in the discussions. The distinctiveness of the seasons was returned to at the end of this group's discussion, where one participant noted that the "colours thing, that's amazing".

Landscape was another recurring theme, although its interpretation appeared more debatable to the participants. One group demonstrated much agreement at the suggestion that Grahame Sydney's artworks had "captured the essence" of Central Otago. Sydney's artworks are prominent in art collections throughout New Zealand; his work Rozzie at Pisa was judged one of New Zealand's top 10 paintings by television programme frontseat in 2006 (Unknown, 2006). Contrasting this, another discussion group was adamant that Sydney's work was not the "essence" of Central Otago; rather it represented the Maniototo. While the Maniototo region is part of the larger Central Otago area, this highlights a factor that would reappear consistently - the boundaries within Central Otago are very strong.

In the first group, weather, climate, and landscape were intertwined in a discussion that drew on 
numerous personal references. Statements from participants in this group began with "when I was a child", "when I was a kid", "as a child", and so on. In fact, for this particular group, climate or temperature was referenced by nearly every participant through a link to their past, especially childhood. Participants in the other groups referenced much more recent personal experiences in their statements on Central Otago's defining elements. In the second group the importance of the weather to the many who work outdoors was noted, while the third group began by talking about the weather and its impact on outdoor activities, including its appeal to the holidaymakers that come to Central Otago throughout the year. These comments are reflective of the participants who made them; one is a long-time local who is actively involved in heritage walks and four-wheel driving, while the other is a new resident but long-time camper. The personal experiences of these individuals make it clear where their point-of-view is founded and provides some reasoning behind why they see these elements as important. The links between important aspects of the region and life history became evident throughout the discussion groups.

\subsubsection{Tourism, Agriculture, and Festivities}

If the natural environment is what Central Otago is traditionally known for, then tourism, agriculture, and events are the contemporary equivalent. Tourist activities, the Rail Trail in particular, are increasingly becoming a large part of Central Otago. Beyond their influence on regional identity, they also serve as an important economic factor in the region's development.

Likewise, agriculture ties in to both economics and tourism. Historically, Central Otago's orchards have drawn money into the region. Since they became common in Central Otago from the 1870s, orchards have been a notable aspect of the region. Certainly, many orchardists have become personalities within the area, while the orchards are famous in their own right. In recent years orchards have been replaced by vineyards and wineries. Beginning to spread over the countryside, these ventures provide another economic avenue for the region. The worldwide appeal of wine also provides Central Otago with a new element in its identity.

The combination of economics and tourism also appears in many of the festivities, celebrations, and events that occur in the region. The added bonus of these events is that they are borne, primarily, out of other aspects of the region. Wine and food festivals draw their inspiration from obvious sources, while Thyme festivals and Rabbit shoots are based on resources within the 
natural environment. Most notable of all festivals is the Blossom Festival. With a history stretching back 50 years, this festival celebrates the beginning of spring - and the fruit season. The timing of this research coincided with the Blossom Festival in September 2006, putting it at the forefront of participants' minds.

Tourism, agriculture, and festivities have been linked together as an over-riding theme due to the economic, social, and historical links between them. However, they are also aspects that are bound together in the minds of the community for the role they play in structuring identity. This is evidenced in the numerous elements that were mentioned in each of the groups; the Rail Trail, Blossom Festival, and wineries mentioned alongside the climate, landscape, and history.

Within recent history Central Otago has become well-known for its celebrations and festivals. Building on a history of these types of event, typified by the Blossom Festival, the region now has many seasonal celebrations throughout the year. In spite of this, only one discussion group mentioned festivals as one of Central Otago's defining elements. With the Blossom Festival's 50 years of history and the fact that it was on at the same time the discussion groups were being held, it was anticipated there may have been some influence on the discussion. The third group talked of the Blossom Festival's place in the region's history and its strong ties to Central Otago identity, while lamenting the difficulties faced by those who organise it every year in the face of growing community indifference.

The notion that other towns within the region are taking the things that were once Alexandra's emerged in the second discussion group. Provincial sporting events, seasonal celebrations, and infrastructure were all mentioned as examples of this. Here the idea that the borders within Central Otago are strong, and each community fairly parochial, also re-emerged as the discussion turned to festivals throughout the region. In particular, Blossom Festival was widely discussed due to the apparent lack of interest from the community in recent years. However, participants praised the attempts being made to involve youth in the 2006 Festival, along with the guaranteed media exposure it provides, and the proud tradition it has established.

The second group discussed festivals and events throughout the region at length. Here, the Blossom Festival was again praised for its longevity and uniqueness, while the Thyme Festival and the multitude of wine and food festivals were identified as being a strong signifier of what Central 
Otago is about today. The Rail Trail was repeatedly noted for its role in representing Central Otago identity, adding to the overall theme that tourist identity is becoming a large part of Central Otago identity. Certainly, tourist pursuits are recognised as being representative of the region.

Recently the Rail Trail was named in sixteenth place on the list of New Zealand's 101 Must Do things in an Automobile Association promotion (Unknown, 2007). This highlights the impact the Trail has had nationally, an impact that is felt especially strongly throughout Central Otago. Much like the weather, the Rail Trail was often passed over in discussions; always warranting a mention, yet glossed over somewhat in its importance. One group noted that the Rail Trail was perhaps more important to the area than locals realised; a point highlighted by the way it was underemphasised throughout the groups.

\subsubsection{Regional History}

Central Otago's earliest history is dominated by Lake Manuherikia. An enormous lake that covered the area 18 million years ago, Lake Manuherikia is chiefly responsible for the current geography and geology of the area. After Lake Manuherikia drained away, the Central Otago basin, as it is now recognised, formed (Wood, 2007).

Central Otago was very much left in isolation until Maori came to New Zealand around 1200 years ago. Maori used the area as a Moa butchery site, an aspect that is remembered in the name of the Maniototo area; Maniototo means 'plain of blood' (Cowan, 1948, p. 1). The extreme climate of Central Otago meant that it was not suitable for Maori to inhabit the area for long periods; however, its location between Moa habitats made it an ideal butchery site. This aspect of Central Otago's history has been well preserved at numerous archaeological sites throughout the area.

Central Otago's European history is grounded in the discovery of gold during the 1860 s. The gold rush that began with Horatio Hartley and Christopher Riley's sensational finds in the Clutha River provided the money on which much of Otago was built. In the 150 years since, Central Otago has continued to build on its proud history. Today, remnants of gold mining and those who pursued it are all over the landscape. Historic buildings dominate town streets throughout the region, while the landscape is getting increased recognition for the links it maintains to the past. 
History is often a major element in the construction of identity, both in positive and negative ways. With the focus of this research being two-fold - on the Alexandra Museum and the Central Otago community - it is important to note history as a defining element to both aspects. While still in its developmental stages when the research was conducted, the Alexandra Museum provides a broad overview of the region's history. In the first phase of the discussion groups, this history was an important and debated theme.

History was the final aspect of Central Otago to be mentioned in each group during the discussion of the region's defining elements. Participants in the first group noted that the history of the region is "fundamental" to Central Otago identity. Several others made points about the markers of the region's history that remain today; noting that, as locals, they are "proud to skite about what we've achieved". The second group also promoted history as important, particularly due to its links to modern day tourism through the Rail Trail and the promotional work of the Promote Dunstan group. The third group focused more on recent history through the Blossom Festival. Although the point was noted here that the region's history, and certainly the traces left of the past, is "mainly European for whatever reasons".

The discussion topic focusing directly on Central Otago community identity drew out responses relating to many different aspects of the region. In the groups the initial statements reinforced that there was a strong sense of community identity within the area, before the discussion moved on to counter this concept. The third group exemplified this when, after noting a strong sense of community identity within Central Otago, they identified that some sectors of the community were "scared of heritage". In particular, they identified the strong visual identity created by the heritage buildings in Naseby, St. Bathans, and Clyde. They also noted that Alexandra has suffered with the destruction of historic buildings around the town. As the location of the Museum, and the recognised centre of the region, Alexandra's lack of a visual heritage identity was identified as detracting from the sense of regional identity.

The notion of a visual identity was repeatedly mentioned in the third discussion group, with particular reference to historic buildings and heritage sites. While the general consensus within this group was that Central Otago had a visual identity, they had previously mourned the loss of much of that identity with the destruction of historic buildings in the region. One participant noted that the tension between "development and origin", or future and past, played a large role 
in the conflict between history and the future in present developments. In discussing this conflict, the natural environment was praised in terms of its continual development through a history of enterprise; maintained from gold dredges to fruit trees and on to wineries. Likewise, the effort to turn heritage sites into viable businesses, such as the Post Office Café and Bar in Clyde, was recognised as an important part of Central Otago today. This was noted for the dual benefits to economy and history that were being achieved.

Throughout the group discussions there were marked differences between opinions on the region's history; one group focused on the past, one on the present, and one on the representation of the past. The disparate elements identified by research participants as being the keys to Central Otago identity make creating any representation a difficult task. As one participant noted, "Central Otago is so many different things to so many different people".

\subsubsection{Museums and Interpretive Sites}

Museums and interpretive sites form the centre of the research. As such, it is validating to see them appear as a recurring theme within the discussion. While the discussion groups were held on-site at the Alexandra Museum, few elements of the initial discussion appeared to be directly affected by the location.

The relatively recent opening of the Alexandra Museum and Art Gallery within the Central Stories building means that Alexandra and the wider Central Otago area has gone without a major cultural hub for some time. The closure of the old Alexandra Museum due to consistent flooding threats, and its temporary home in a number of different locations, has ensured that the new building is the most comprehensive and professional museum complex the area has seen.

Outside of the Alexandra Museum there are numerous other interpretive sites within the Central Otago basin. The majority of Central Otago towns have information centres and a small museum or historical society of their own, with many towns in the area featuring aspects to which their history is indebted. Locations like the Clyde dam, the Bendigo diggings near Cromwell, and the Earnscleugh Tailings across the Clutha River from Alexandra, are all sites that require and feature interpretations and displays. Whether or not these locations are seen as representative of the region, or even the specific area they relate to, is very important to the tone and understandings 
of this research.

The discussion in the first group provided the most comprehensive critique of the Alexandra Museum. One respondent noted that the region needs a "permanent showcase", which many participants intimated they would like the Alexandra Museum to be, although, to the participants, it currently falls short. While much of the discussion focused on the Alexandra Museum in its current state, many of the participants referred to personal experiences with other heritage sites and historic representations. Those participants with long family histories in the area often referred to the achievements of their family members in Central Otago, while more recent residents talked of experiences at the Alexandra Museum when it was located on its former site, and of the visitor experience that was once offered at the Alexandra Courthouse.

\subsubsection{Community}

While the museum environment is at the centre of this research, it is surrounded by the notion of community and its identity. As the first phase of the discussion group focused on the construction of identity outside the Alexandra Museum, the notion of community was explored in some detail. This aspect of the discussion created a great deal of debate amongst the research participants and also covered a range of topics and notions.

The many aspects that make up Central Otago's past, present, and future, shape and inform notions of community identity. This creates an intertwining between many of the other key themes within this one. This factor is important in shaping this research; placing some importance on those themes and highlighting them as being very specific to this research and its aims.

The wider community came through as a prominent aspect in participants' day-to-day lives. In the second group, it was noted that the size of the community and relaxed lifestyle were reasons why people were here. The point about a relaxed lifestyle was debated somewhat amongst the group; the overall impression being that there is an 'image' of Central Otago as providing a relaxed lifestyle, although this is not necessarily the case. Again, as with the Grahame Sydney debate regarding the landscape, the perceived 'image' of Central Otago comes into question. Participants did, however, note the fact that their lifestyles are not relaxed was due to the opportunities they have to be involved; being busy "through choice, as opposed to imposed hassles". 
In the final group, the discussion on community that emerged began from one participant talking of their experiences as a new resident in the area. Those who had been in the region longer talked of how the people in the community were welcoming to new people. However, this developed when further discussion highlighted that people have to get out and get involved in the community before they feel they are a part of it. The notion of Central Otago community was often compared to living in the city and differences between the two. The feeling of belonging within the community was considered one of the benefits of the Central Otago region.

Not all aspects of community discussed were entirely positive. Although this was due, in some respects, to the focus being less on the community and more on the governance of it. Local government emerged as a theme in the first group, where the experiences of those in the group drove the discussion. In this group the idea was put forward that small communities in New Zealand are over-governed with people needing "planning for this and planning for that". However, the discussion quickly changed from the failings of government to the failings of the community. In particular, comparisons were made between several communities throughout the area and the effort each puts into their own festivals and activities. It was recognised that Wanaka and Queenstown have been very proactive in promoting their seasonal festivals, while Ranfurly has worked hard on its Art Deco theme and Omakau has embraced the Rail Trail. On the other side, participants noted that in Alexandra it is the same people putting in the effort to organise and run things. With "no engines coming in to replace the engines that have been doing it for the last ten years" there is a sense that Alexandra is falling behind the rest of Central Otago.

The participants in this first group were mostly long-term residents, with much of the discussion led by a participant who made the statement "when I was at school in 1936". This long history within the region, which was shared by much of the group, meant that many participants have seen Alexandra's rival communities build strong events that have stolen the thunder from Alexandra's own events. While the participants in the third group also picked up on the council theme, their personal experiences meant a vastly different approach was taken within the discussion. The discussion in this group was not led by any one individual, meaning a balance of opinions were gathered. This group also tended to be younger than the first group, with participants who had been involved with Central Otago for a shorter length of time. 
In the third discussion group the focus was on the difficulties that people have had in their own dealings with the Central Otago District Council (CODC). This particularly focused on the length of time taken to get things achieved as well as issues with decisions made. The balance of the group made this discussion particularly interesting with a couple of participants directly affected by council decisions, other participants adding unbiased views, and one participant a member a local community board - a feeder to the CODC. The apparent backlash against the council is interesting considering their role in fostering community identity. In 2005-2006 the CODC put a great deal of time and effort into re-branding the identity of the region; implementing particularly detailed community research. While this is mainly from a tourism viewpoint, it is interesting to note that many similarities exist between the identity created by the council and the one being described by the participants within these groups. The re-branding's focus on landscape, history, climate, and activities is one that was reinforced by the discussions within the groups for this research.

While all the groups were initially adamant there was a strong sense of community identity within Central Otago, each group talked of the things that inhibited that identity. Within the first group this discussion started with the identification that pride in Alexandra is "inherited", and few people are stepping in to keep that going. The influx of people moving to Central Otago from other areas was noted as a reason for this; people who do not know the region's history and are only here for a short time. This notion was also mentioned in the second group, where the longtime locals talked of the changes that have occurred over the last five to ten years. In particular there was a feeling that the semi-retired, or "change-of-lifestyle", people who have moved to the region recently have impacted upon the sense of identity. This notion of identity is directly related to community pride and those aspects that create that pride.

Another detracting factor that emerged within the first group was the filtering out of local infrastructure. Alexandra was once the hub of Central Otago's commercial and public sector; many government departments and major stores were based in the area. These industries have been dispersed around the region - along with the people they employed. This aspect was seen by the group as impacting upon the sense of identity with the region.

While the initial reaction to the notion of Central Otago's community identity was positive throughout all the discussion groups, much of the talk that followed centred on the failings of 
Central Otago's community identity. What emerged from these discussions is a real sense that Central Otago residents feel strongly about their region, although they see things that detract from that - aspects that undermine the sense of belonging within the community.

It was highlighted in the literature review that social inclusion work has been seen to have positive repercussions for fostering community identity. The responses gathered within this research identify Central Otago as a region that people want to live in and be part of, yet the community sees many inhibiting factors to its identity. This factor is notable moving forward into phase two of the discussions, where the emphasis shifted to the Alexandra Museum. Although the Museum is not actively involved in social inclusion work as such, it is important to evaluate how it has approached the detracting aspects of Central Otago and how participants respond to that representation.

\subsection{Participant Frames of Reference}

Throughout each of the themes described in this chapter there is an over-riding theme that illustrates how participants construct their views on Central Otago identity. Introduced by Perin (1992) and Silverman (1995), the role of frames of reference in the museum experience has been detailed in Chapter Two of this study. That frames of reference came out as a vital aspect in the construction of community identity is an important realisation for understanding how the Central Otago community constructs its identity. Particularly, this theme deals with the personal elements that participants associated with Central Otago identity. The fact that this theme emerged as dominant in the discussions reinforces the impact that personal experience has in the construction of meaning.

Within the discussion groups there were a wide range of ages, backgrounds, and genders. One variable that emerged as having a large impact on the understanding of Central Otago identity was the length of time spent in the area. Some participants had around 70 years experience in the region, while others had been here for a year or less. Common to all participants, however, were elements of experience that made Central Otago special, unique, or home, to them. That these personal elements were used to back up opinions on festivals, landscape, events, weather, and even local government, demonstrates how they influence the overall perception and understanding of the area. 
In between discussions on the climate, landscape, Rail Trail, vineyards, and history, a number of other aspects of Central Otago were mentioned. From the Blossom Festival to the 'central' location of Central Otago, these aspects identify the different views people have of Central Otago. While there are the base elements that Central Otago's identity is built on, these other aspects breathe life into it and make people feel the region offers something that is unique to them. One participant loved the fact he could go fishing whenever he wanted, and probably would not see another person the whole time. Another participant, relatively new to the area, enjoyed the welcome given to them by the people of the area. Outdoor pursuits, the lifestyle, regional boundaries, and other aspects, all build up to create an image of a region that is diverse, personal, and sited on a number of base elements.

The discussion topic focusing on the aspects of Central Otago that impact most upon participants opened a broad range of discussions - few directly related to the topic at hand. More important, however, was drawing out the personal elements of Central Otago in the minds and eyes of the community. What emerged is a picture of a diverse region where the markers of identity are largely defined by personal experiences. The fact that many discussions began by focusing on childhood, work, or activity-based experiences, reinforces the role that the personal has in constructing community.

In the first group, those participants who had resided in Alexandra for some time related to their cumulative experiences in the region, while those who had lived elsewhere for extended periods often related to holidays in the area. Likewise, people who worked in retail often noted the importance of people in their day-to-day lives, while people who worked outdoors or were actively involved in outdoor activities related the notable aspects to that part of their lives.

In describing Central Otago's characteristics if it were a person, participants used many single word adjectives; focusing on aspects that drew from the landscape and the region's festivals. Words like "alluring" and "colourful" were common as the group focused on the "feel good things". In comparison, one group followed on from previous statements about New Zealand being a young country, by noting that Central Otago had "old bones and a young heart". As much as anything else this group discussed, this description was widely agreed with. Aimed at gaining a slightly different take on the region, this question drew out personal responses from participants 
that highlighted their feelings about Central Otago.

One further interesting point to come from the second group was the statement from the teenage participant that "there isn't anything to do [in Alexandra]". In reply to this, one participant noted "we talk about all the things that we haven't got time to do in our lives, and yet kids [complain there isn't anything to do]". Emerging through all these discussion topics is a very real notion that the image and identity of Central Otago has a lot to do with time factors; age and length of time spent in the region. The role of personal experience also cannot be overlooked for its importance in the construction of community identity.

Of all the themes that became evident throughout phase one of the discussion groups, the influence of personal experience was perhaps the most notable. This adds value to current theories on meaning making and reinforces those that focus on the role of the individual in constructing experience. In the second phase of the discussion groups the focus of this research shifts to the representation of Central Otago identity within the Alexandra Museum. Throughout the analysis of the data collected in the second phase it is important to cross-reference factors back to the important themes from stage one; personal experience in particular.

\subsection{Summary}

The markers of community identity noted and discussed in this chapter form the basis for the construction of identity within the Central Otago community. These markers are built on a number of defining aspects that the community sees as important to the identity of the region. The interpretation of these aspects is open to the individual, whose own relationship to the region is impacted by their experiences within the region. These experiences commonly relate to family history in the area, childhood experiences, and work and activity today. With the role of personal experience already identified as an important part of meaning making within the museum, it is encouraging to see it emerge as a key role in making meaning within the community. The second phase of the discussion groups looked at this concept within the Alexandra Museum, focusing on the aspects that participants use and relate to in constructing meaning in the Museum. 


\section{Chapter Five}

\section{The Discussion Groups (Phase Two)}

The second phase of the discussion groups began with the participants being given an opportunity to view the Alexandra Museum's exhibition spaces. The discussion that followed this centred on concepts that reflected those asked in the first phase, with the focus shifted to the Museum representation of Central Otago.

Within the Alexandra Museum's galleries participants viewed a large display on the geology of the region, made up of a display case featuring rocks and minerals from throughout the region, alongside an audiovisual presentation. There were also static displays on the history of Alexandra, the Blossom Festival, the wine industry, early explorers, goldmining, and merino. A large display had also been made up surrounding the relocated stairs of the Bendigo Hotel, while a small theatrette screened films on the history of the region. Outside of the main exhibition space, displays had been set up on winter photographs and social history. The Museum's art gallery featured a display of works from a contemporary local artist.

The five key themes that emerged within the first phase of the discussions are readdressed in this chapter with regards to their role in representing Central Otago. These themes formed the basis of the identity that participants constructed within phase one. As such, they are an important element in the representation of that identity. What this phase of the discussion attempted to discover was the role these elements played in the museum experience; creating a comparison between construction and representation in the construction of identity.

\subsection{Key Themes'from the Discussion Groups}

The five themes that emerging during phase one of the discussions are re-evaluated within this chapter. As participant-identified elements that are important to the identity of Central Otago, they become a key element in the representation of that identity. This is particularly true in this case, where the interpretation of the Museum identity by the community is an important factor. 
Again, these key themes are:

1. The Natural Environment

2. Tourism, Agriculture, and Events

3. Regional History

4. Museums and Interpretive Sites

5. Community

While the emphasis shifted in the second phase of the discussion to focus on the Alexandra Museum's representation, these themes once again emerged as important aspects in the participant interpretation of the Museum representation. Some themes became more notable

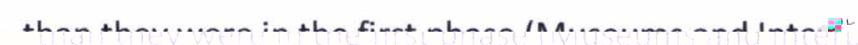


outcrop and the tussocks planted alongside it. This landscape representation was seen by participants as being highly representative of the region as a whole.

What is interesting about the participant interpretation of the skink case is their identification of the iconic elements of the landscape presented within. The skinks within the case are some of New Zealand's most endangered creatures, housed at the Alexandra Museum as a part of a conservation and breeding program that began at approximately the same time as the Museum opened. Even with no labelling or text describing the landscape represented within the case, participants identified this single element as one of the Museum's most representative interpretations of the region.

While this landscape representation was largely praised, participants in two of the discussion groups noted that it only went a small way into representing the flora and fauna of the region. Some participants approached this notion in a very practical way, offering ideas on how to involve people further in the current landscape interpretations of the Museum. Others centred on elements of landscape, climate, and habitat that were missing within the Museum from the Central Otago they constructed in phase one. Thyme was one of these elements, identified as being "the smell of the area". In discussing thyme, participants referred to their own experiences "walking the dog" and "climbing in the hills" that had made thyme, particularly its smell, an important aspect in Central Otago.

In phase one, participants were often quick to focus on elements that set Central Otago apart from the rest of New Zealand. This theme continued in phase two where participants in one group spent some time discussing how thyme only grows wild in two places in the world; Central Otago and Spain. It is interesting that thyme was given such a large prominence in this phase of the discussion as it was only mentioned briefly in phase one. While it does not appear to be an important part of community identity, it seems the community still feels it is an important part of the representation of their community.

Climate was a highly regarded element in the construction of Central Otago identity, identified as the reason why people live here and why people visit. However, in phase two climate was largely forgotten in favour of other elements. One element of the Central Otago climate that did remain a talking point was the influence the seasons have on the area. This element was a common 
thread throughout the first phase of the discussions, with people often referring to events throughout the region and their basis in the seasons.

In discussing the seasons within the context of the Museum, participants built a comparison between what is happening in the community beyond the Museum and what they would like to see happening within the Museum. The creation of "timely" and "lively" displays that celebrated the region was seen as missing within the current display space. This aspect will be discussed further in the next section, however it should be noted that the seasonal extremes and their effect on Central Otago, tourism in particular, was seen as an important part of the construction and representation of the region.

\subsubsection{Tourism, Agriculture, and Events}

This theme became a major talking point within the discussions for phase two, both in regards to aspects that the Museum has used to represent Central Otago and where current representations are lacking. In phase one, this theme was important without being vital; participants identified these elements as important, although they tended to focus more on their failings. In phase two, this theme becomes a dominant one, creating an interesting contrast between the identity of Central Otago and the representation of Central Otago.

It was under this theme that participants placed the most emphasis on the importance of seasonal displays. The desire expressed within the discussion groups was for there to be displays within the museum that celebrate the events, harvests, and celebrations within the region. At the time of conducting these groups it was spring, a time which heralds events around fruit trees blossoming, merino wool, thyme, and wine. Each of these emerged as aspects of the season that participants believed should be a part of the representation of their region.

Aside from thyme, all the aspects outlined by participants in the discussion of this theme were represented within the Museum. With the Blossom Festival celebrations in full swing, this was one event in particular that emerged in this phase as prominent. In the first group's discussion, the Blossom Festival was mentioned for its seasonal importance and participants noted that this seasonal element was not mentioned in the Museum's interpretation. In the other two groups the discussion on the Blossom Festival centred much more on its role in personal experience, 
memories of which were triggered by the Museum display.

The current Museum display focusing on the Blossom Festival features an ornate decoration covered in the paper flowers that Blossom Festival floats are well-known for. The centre-piece of the display is a number of photographs from the past fifty years of Blossom Festival celebrations. These photographs served as a strong visual initiator of memories in participants. Long-time residents thought back to memories of when they were on floats ("I've got memories of me being on the float - many, many years ago"), or when their children were on floats. Participants who had resided within Central Otago for a shorter length of time still had memories tied to the Festival, one of these participants noting that one of their earliest memories in the region was of helping out with "a float for a swimming club".

Agriculture was primarily mentioned in this second phase of the discussions for the lack of attention placed on it within the gallery. Orchards in particular were noted as an element that was missing from the Museum display. Participants recognised that Central Otago was well-known outside the region for its fruit industry ("It's still regarded as the best pipfruit"), as well as being an integral part of the region's history. This aspect is particularly interesting in that orchards were seldom mentioned in the first phase of the discussions, where history and the foundations of the region were often talked of. Countering this observation is the way that participants in the second phase of the discussions tended to focus more on the more recent and contemporary elements of Central Otago.

One of the elements of contemporary Central Otago often mentioned in phase two was vineyards and wine. Participants noted that this aspect, alongside other contemporary elements of the region, was largely missing from the display. In spite of this, participants still found ties to the existing representations in their personal experience. One participant spent a great deal of time looking at the existing wine display, quickly noting the relevance it has to their daily life upon returning to the discussion group environment.

\subsubsection{Regional History}

Surprisingly, regional history was downplayed in phase two of the discussion groups. This was no doubt due to participants generally focusing on the more contemporary side of Central Otago in 
the discussion on the representation of the area. In fact, there were very few references to regional history in this phase of the discussion groups. When it was mentioned, different aspects were highlighted compared to the first phase of the discussions.

Perhaps expectedly, the region's goldmining history was mentioned. In each of the discussion groups the Museum's gold display was mentioned early on in the discussion about the aspects of the Museum that best represented the region. The Museum features a large stack of 'gold' bricks that represents the equivalent of all the gold taken from the region during the peak of the goldrush. It was this display that prompted the greatest discussion from participants, each group recognising the foundation of the region is based in its goldmining history.

Another aspect of the region's history to come out as important in the representation of Central Otago was the hydro-electric history of the region. Surprisingly this aspect was not mentioned at all in the first phase of the discussions. This reflected a trend in this second half to focus on aspects of the region that were either contemporary, or placed Central Otago as a vital part of the nation. The region's hydro-electric history is certainly part of the latter, with one participant particularly concerned about there being "not a thing about the Roxburgh dam, there's nothing about the Clyde Dam, there's nothing about the Teviot Power Scheme or the Roaring Meg". This list of electric-generating achievements in the area leads to a further element of regional history, the place of water in the region's history.

While the electric power schemes mentioned by participants rely on the rivers and waterways around the region for their power, the role of water in representing the region was largely underplayed. One participant talked of the "bridges we've had which have washed downstream", and others briefly mentioned the fact the river was not represented within the exhibition at all. The role of the river in representing the region was only mentioned in terms of its historical significance, a factor that is particularly interesting given the general focus on more recent aspects of Central Otago in this phase of the discussion. With outdoor pursuits identified as being an important part of Central Otago identity in phase one, it is notable that they were not mentioned as having a role in the Museum representation of the region. 


\subsubsection{Museums and Interpretive Sites}

While this theme was identified as important in phase one, it was less focused on in the discussions than the other themes. In phase two this trend was reversed as the focus on the Museum and representation had an effect. The discussions in phase two that revolved around the museum theme were in depth and varied; ranging from suggestions on the financing of the Museum, to the role of museums, to critiques on its displays and interpretations.

One of the major talking points regarding museums was questioning what the role of a museum is, particularly in a small community. Various participants described the role of the museum using words like "nostalgia", "history", and "old stuff". Many of the initial discussions on the role of a museum revolved around the notion of "the past being brought to the attention of the present". These views appear to give an image of the museum as a repository of history, although it again must be noted that participants were quite vocal in their discussion of more recent elements of Central Otago and the role they play in representing the area.

This focus on contemporary Central Otago was reinforced through further discussions in phase two where participants noted that a museum needs to show the "the progression of life". This statement was made with particular reference to the role of the Alexandra Museum in showcasing the area, an issue that was reiterated in other groups where they desired to see a museum that was "relevant" and which showed the "then and now". This notion of the "then and now" was one that participants often referred to, describing how many functions of the museum need to provide a "balance".

The notion of "balance" became an important point of discussion in relation to another issue surrounding the role of a museum; who should it serve? With the Alexandra I-Site ${ }^{2}$ located in the foyer space of the Central Stories building, the question was raised over whether the Alexandra Museum should be catering to visitors or locals. While the general consensus was that both should be catered to, the reasoning was often quite varied.

\footnotetext{
${ }^{2} \mathrm{I}$-Site is the name given to Information Centres that are accredited members of the I-Site Visitor Information Network.
} 
With some focus in this phase of the discussion being placed on Central Otago's contemporary aspects as important in the region's representation, the visitor element came across as a strong part of who the Museum should be serving. Participants recognised that the fact that "in Central Otago we're trying to promote tourism as part of the area" meant the Museum had a role in presenting the region to visitors. Certainly, within each of the discussion groups, the Museum was noted as being aimed, primarily, at visitors at this stage in its development.

The observation that the Alexandra Museum presently caters to visitors more than it does to the community came out in each of the groups, with much discussion stemming from this idea. One group's discussion revolved around the importance of visitors to the museum in a purely economic way. While this group identified that the Museum was currently aimed towards visitors, they felt more could be done to "extract money" from these visitors. Another group also discussed the need to have a viable income stream and the importance that visitors play in that role.

It was also mentioned that the I-Site plays a role in the way people's views on the Museum are currently structured. One participant noted that the I-Site is "telling part of the story", and that the Museum should be focused on telling the "story of Central Otago and the surrounding areas". Within this participant's group, the discussion on who the Museum should be serving was often talked of in relation to the I-Site's role. The point was made that the two should be working collaboratively in the creation of a "cultural hub" within the region.

Participants often talked of the areas in which they felt the Museum could be improved. Here, the Museum was often applauded for looking "like it's going to be a great facility". However, it was also noted that the Museum is also missing some important representational elements of Central Otago (as discussed earlier in this chapter), while elements of its current operation were "not user friendly".

The greatest element of concern throughout the three discussion groups was the feeling that the Museum was not doing enough to cater to, and attract, children to the institution. As some participants had teaching backgrounds, this idea was approached in a very practical way by many; identifying that, currently, they "just wouldn't bring their classes". Other participants simply noted that there were not many attractions that would appeal to children or that would encourage them to sit, learn, and listen. In this respect, participants felt that the current 
representation of Central Otago was too focused on "written stuff rather than more visual", a representation that did not reflect the interactive nature of the region.

\subsubsection{Community}

Community was a major theme in phase one of the discussion groups, a factor that reflected the focus on the community construction of identity. In this second phase, where the focus was on the Alexandra Museum and identity representation, community became less important within the discussions, while the Museum became more notable.

In the previous section the role of the Museum was discussed as participants sought to determine who the Museum should be servicing - community or visitor. Aside from this aspect, community was largely downplayed in phase two of the discussions. However, many elements from phase one that related to the community theme resurfaced under different themes in this second phase.

One participant summed up the role that the Museum plays for the local community by saying that they "think, as far as the local community is concerned, it has a responsibility to protect the history, our history, in a way that can be accessed both by school kids, as well as by locals of any age". This statement reiterates much of the community discussion in phase two, where the Museum is seen as both the store of Central Otago's history, and the place where it is represented for the community, and the world, to see.

\subsection{Summary}

The critique of the Alexandra Museum's current representation of Central Otago drew on various elements of the region. While many of these elements reflected the aspects participants had earlier identified as important in the construction of their community identity, other ideas were introduced and previous ones ignored. In analysing the Alexandra Museum's representation, participants placed a large emphasis on what they wanted to see representing Central Otago rather than what they currently saw within the Museum. This aspect reflects two distinct community identities created by the participants, a community identity and a visitor identity. This notion and other conclusions to come from this study are explored further in the next chapter. 


\section{Chapter Six}

\section{Conclusions}

The two phases of the discussion groups conducted for this study reflect the dual aims of the study overall. In the first phase the discussion centred on the construction of community identity. In analysing this data five key themes became evident that research participants repeatedly referred to in their construction of the Central Otago community identity. Throughout these themes, the concept of participant frames of reference became an important aspect of the discussions. This factor, alongside the identified themes, provides an insight into how a community constructs and understands its own identity.

In 6.1, the conclusions arrived at through an analysis of phase one of the discussion groups is presented. The analysis of these discussions presents the important aspects in the community construction of identity, and highlights the importance that frames of reference have in the construction of identity.

The conclusions from phase two of the discussion groups are detailed in 6.2. Where phase one focused on the construction of community identity, phase two centred on the representation of that identity. Again, frames of reference emerged as a key aspect - alongside the themes already identified in phase one. The discussion of phase two's conclusions focuses on the impact these conclusions have on the museum and museological theory.

In the final section of this chapter, the results of this study are summarised. As the focus of this study was both on the community and the museum, the summary presents elements that are important to both of these participants. As identified in Chapter Two, much museological research has begun to focus on the relationship between museums and communities. Nowhere is this relationship more vital than in small communities like Central Otago. How this relationship has played out and been explored throughout this research is noted in the summary in section 6.3. 


\subsection{Conclusions from Phase One}

Emerging through the data gathered from the first phase of the discussion groups is a complex image of how identity is constructed in Central Otago. The construction of this identity within the community was the focus of this section of the discussion groups. As noted, five central themes became evident across the groups. These themes drew in factors relating to the physical and social environment, as well as aspects that relate to the theories of museology and identity construction. While each group approached these themes in different ways, their emergence within all the discussions highlights how important these themes are to the construction of community identity within Central Otago.

The five themes outlined in Chapter Four centre on the elements that are important in the community's construction of Central Otago identity. Within these themes, participants identified many aspects and issues that are involved in the complex process of constructing Central Otago identity. These aspects provide an insight into how identity is constructed by the community.

One aspect to consider is that of the region's perceived image. A noted issue under many of the discussion topics, the image of Central Otago as it is perceived by outsiders is a complex one. Participants felt that many misconceptions existed about the area; often spread by the media. Weather, landscape, community and, to an extent, history, were all elements seen as commonly being affected by stereotypes or misrepresentations.

This relationship between reality and representation is one that museums often struggle with. Certainly, within this research it became evident that personal experience plays an important role in a person's interpretation of their community. This identifies the difficulties inherent in trying to present any one 'reality' - a notion meaning making theories are attempting to steer museums away from. What is notable is the way that stories and interpretation become important. When given a topic, participants were all able to relate to it through their own personal experiences. Weather turned out to be a surprisingly good example of this; sparking numerous discussions, particularly related to childhood memories. This finding reinforces the writings of theorists on meaning making who have identified the role that personal experience plays in the interpretive process. 
Diversity is another identifier of the Central Otago region to come from the first phase of these discussion groups. It was also a factor that the Central Otago District Council picked up on in rebranding the region. The 2006 marketing campaign is based upon the slogan "a world of difference". Further reinforcing this was the statement by one participant that Central Otago "is so many things to so many people". The issues involved with interpretation are always a challenge for museums; do they have the right objects/stories/people/designs? However, these challenges become more difficult in an area like Central Otago, where it is commonly recognised that the regional identity is made up of so many elements.

The defining features of Central Otago identity as identified by these discussion groups are built on many factors. Firstly, Central Otago is a region defined by the natural environment. It is an area that is instantly recognisable, and that cannot be mistaken. From the schist rock, to summer sun, winter frosts, and barren landscapes, Central Otago is very clearly defined by its location, landscape, and climate. Furthermore, the numerous outdoor pursuits, markers of history, and events across Central Otago were all identified as reasons why people live here. Each of these aspects also prompted statements on the personal experiences people have had within the region. These experiences are important in each individual's interpretation of Central Otago.

The research also identified that Central Otago residents feel very strongly about their region; they are proud and enjoy living here. However, they also see the dynamics of the region changing. The loss of infrastructure, fading interest in events, and other towns' proactive promotion have seen Alexandra's role as the centre of the region change. While many defining aspects of the region are still identified as those that are synonymous with Alexandra, many of them are now aspects that encompass the entire region. This is certainly an important development for the identity of the region as a whole.

Adding to this is the identification of strong community divisions within the area. Within the discussions Alexandra was identified as being 'Central Otago' while other towns in the area fell under Maniototo, the Lakes District, and Teviot. These strong divisions further demonstrate a fractured identity for the region, although they do promote strong individual community identities. 
While all the discussion groups noted the importance and role of history in Central Otago identity, the pride seems to have gone out of this element. Instead much of the discussion on history was on its destruction, and the lack of a strong representation of it. On the other hand, the region's festivals were commonly heralded for their successes and the role they play in representing the modern day Central Otago. This change in dynamics highlights a region that the community wants to see as forward moving, yet respectful to its past.

\subsection{Conclusions from Phase Two}

The notion of Central Otago as a region that has strong ties to its past yet is proud of its present is reiterated through the collated discussion group data from phase two. In phase two participants discussed at length the Central Otago represented within the Alexandra Museum, focusing on its strengths, weakness, and where the future of that representation lies. While the focus of phase two centred on the representation of Central Otago identity, and phase one on the construction of that identity, there were many parallels between the discussions in each phase.

One aspect of the region that emerged as important in both the identity and representation of Central Otago was the landscape. In phase one, the region's distinctive landscape was noted as a highly important aspect in the Central Otago community's identity. In phase two, participants highlighted how accurate the Alexandra Museum's representation of this element was - many participants believing it was a positive depiction of one of the region's defining elements.

An interesting factor in the response to the Museum representation of the Central Otago landscape was the lack of interpretation surrounding it. Within the Museum several elements indirectly refer to the landscape of Central Otago. While there is an audiovisual display on the geography of the region, and a small display of geology, there is little in the way of interpretation that directly addresses the landscape. Indeed, the element that participants most aligned with the identity created in phase one was the landscape recreated in the skink case - a representation that features no interpretation. This lack of interpretation highlights the importance of personal experience in the interpretation of the landscape. Participants noted the Museum representation as being an accurate one, without needing any prompting or interpretation regarding it. Having noted the role the landscape plays in the construction of community identity in phase one based on personal experiences, it is interesting to see this repeated in the reaction to the Alexandra 
Museum representation.

While landscape was an important element in both aspects of this study, others were focused on more in one phase than in the other. In phase two, participants spent some time talking about elements of Central Otago that were missing in the Museum's representation of the region. Some of these elements, such as vineyards and festivals, were also a large part of the discussion in phase one. However, several elements were only noted in the second phase.

These elements are worthy of further investigation as participants saw them as worthy of representing Central Otago, yet did not feel they were an important aspect in the construction of the community identity. The most prominent of these aspects were thyme, orchards, and power generation. Each of these were mentioned as aspects of the region that are unique to Central Otago and, as such, are aspects to be proud of. Thyme was discussed in relation to Central Otago being one of only two places in the world where it grows in the wild, while orchards and power generation were discussed as aspects of the region that highlight how Central Otago has contributed to the nation as a whole. That these elements were not discussed in phase one, yet became important in phase two, highlights them as aspects that participants do not necessarily see as contributing to their sense of identity. However, they appear to be aspects of the region that separate Central Otago from other areas, making it unique and giving it that point of difference that they want to promote to visitors.

With these elements appearing in phase two after having been passed over in phase one, it is no surprise that there were also elements mentioned in phase one that did not transfer over into the discussion on representation. The most notable of these was the Rail Trail, which was one of the most talked about aspects of the region in phase one. That the Rail Trail was not mentioned even once in phase two is intriguing given the recognition given to unique elements of Central Otago during phase two. The neglect to mention the Rail Trail is further troublesome owing to the focus on the more recent aspects of Central Otago in discussions. However, participants did tend to pass-over the need to depict Central Otago's outdoor pursuits in the representation of the region. This only goes some way into analysing why the Rail Trail is so important to the construction of community identity, yet seems to have little value representing the region. Perhaps the only qualification for this is the focus on the Museum in the second phase, which has no display on the Rail Trail and also takes the emphasis away from other similar sites or attractions in the region. 
Another notable aspect to appear in phase one but not in phase two was the weather and climate - an aspect that was particularly dominant in phase one. While this aspect was a key in the construction of identity, participants did not mention it in regards to the representation of the region. What they did focus on, however, was the impact of the seasons. This element was also a strong part of phase one, often mentioned in conjunction with discussions on the general climate of the area. In phase two a large emphasis was placed on the role that the region's recent history and contemporary events have on the representation of the region. The focus on the seasons was an extension of this as participants reiterated the seasonal nature of Central Otago's events and festivities. These elements came out as a particularly strong aspect of Central Otago representation; in particular the Blossom Festival was discussed as it provided many examples of personal experiences with these events.

The importance of these events to the representation of Central Otago was further developed through debates on what participants wanted the Museum to 'be'. Throughout each of the discussion groups, participants repeatedly called for a museum that was "lively", "timely", and "relevant". The expression of this desire came especially through the idea that the Museum should reflect what is happening in the community at the time. Part of this came from participants recognising that the location of the I-Site within the Central Stories building alongside the Alexandra Museum would provide many visitors with their first experience of the region. As such, participants identified that the events happening within the community should be represented within the Museum, as much for the benefit of out-of-town visitors as for anyone else. This again reflects the desire to present a vibrant, alive community to visitors to the area - a representation that contrasts with the community's own identity. This identity was constructed with a desire to live up to these adjectives, yet was recognised as not living up to those expectations in the community's own eyes.

Discussions on the role the I-Site plays within the Central Stories building led to debate on what the role of the Museum should be. The general consensus throughout the groups was that the Alexandra Museum should be a repository for the region's history - safeguarding it for the future - while still presenting the region to visitors. This dual aim provides an insight into the image of the region being built through this study. In particular, it rationalises some of the discrepancies between the construction of identity and the representation of identity. As part of this, 
participants noted that the Museum and I-Site should be working together to present a holistic view of the region; incorporating history, community, events, and the geographical features of Central Otago.

This aspect of the Museum operation is reflected in several comments by participants that emphasised their desire to see the Museum develop into a solid representation of 'their' Central Otago. This notion is tied up in the analysis of the discussion here, where participants define two Central Otagos: one that defines their community and another that represents their region. While these two Central Otagos have many similarities, they also have many points of difference and are built on unique aspects and views of the region.

\subsection{Summary}

The construction of community identity is a complex intertwining of many elements including the personal experiences individuals have with those elements. These cover aspects of the community that are positive and negative, historical and contemporary, economic and social, cultural and individual. What they all have in common is a link to those personal experiences for each individual member of the community.

Interpreting the representation of community identity is less open to personal frames of reference than the construction of identity. While the community undoubtedly still refers back to their own experiences and knowledge in deciding what is appropriate to represent the community, they tend to focus on elements that they are proud of more than elements they have direct contact with. In this process, assumptions are made as to which aspects of the region are the most notable on a scale that considers more than their immediate community.

Participants in this study constructed the community identity of Central Otago as one that is based on a strong pioneering history, and has been added to by continuing progress through recent developments. Their community is one that they are staunchly proud of and are keen to see continue developing. In constructing this identity, participants called upon many repertoires of knowledge and personal experience within the region. These experiences defined many of their views on the region, and informed much of the identity that was constructed through the study. 
In the representation of this identity, participants continued to focus on the development of Central Otago through the continued development of the Alexandra Museum's representation of the region. Calling upon experiences in other museums, they have identified the current Museum representation of Central Otago as being strongly representative of the identity they created in phase one in some respects, and being quite different in others. The balance required to accurately reflect Central Otago back to the community and to present it as an interesting, alive, and vibrant place to visitors is one that participants identified as being of great importance to the success of the museum. As one participant noted of the museum:

... it 's got to be relevant to both people here - I think that's maybe the key thing-and it's also got to then be reaching out to other people to make sure they can access the sense of Central Otago.

This study exemplifies the complexities of the relationship between the local museum and the local community. As theorists have looked towards building on this relationship to create stronger ties between the two parties, theories such as those of social inclusion have been developed. Early indications from social inclusion studies indicate the community-wide benefits that can be seen when these projects are implemented (Guetzkow, 2002).

The conclusions from the study conducted here identify the various aspects that the community refers to in constructing their community identity. When the focus is shifted to representing that identity the community calls upon a different set of references, essentially creating a different identity. While the analysis of social inclusion work highlights strengthening community identity as a positive outcome of the implementation of such projects (Matarasso, 1997), my study identifies how difficult it is to identify a unified community identity.

In turn, this reinforces the need for museums and communities to work closer together to represent the community in a way that is relevant, identity-affirming, and accurate. While achieving a representation of community identity that everyone within the community will agree with is an impossible goal, the creation of positive representations is not. Museums are beginning to realise this as they seek to involve the community to a greater extent in their own representation.

My study examined the construction of community identity as the community sees it, before investigating how that identity was, and could be, represented. Bringing the community into the 
museum environment and allowing them the chance to speak on its relevance to their community identity opened up the opportunity to explore the dynamics of the museum/community relationship. While this relationship is complex and ever-changing, the implementation of current theoretical notions can assist in understanding it.

Within this study, visitor frames of reference emerged as a key element in the construction of identity. These frames of reference were often referred to by participants as they attempted to decipher their regional identity. The impassioned response to phase one of the discussion groups highlights how important this aspect is. The diminished importance of frames of reference in phase two demonstrates the current stage of development the Alexandra Museum is in. Participants instead focused on the elements of the region they wished to see represented within the Museum, elements that reflect a desire to see themselves and their vibrant region within the Museum.

Further research into this field is required in order to better comprehend the interplay of identity construction and representation. While my study goes some way into introducing the logistics and variables of this, more emphasis needs to be placed on the role of the visitor in the museum experience.

The aims and objectives of this thesis are reflected in the Otago Museum's most recent exhibition development. During the summer of 2007/2008, the Otago Museum is planning an exhibition entitled Otago's Otago. This exhibition calls for Otago residents to submit the aspects they feel best define the region to the Otago Museum, with the top one hundred aspects being put into a exhibition to open in late 2007. Otago's Otago is the practical implication of the theoretical investigation under taken within my study. The success or failure of such an exhibition will go a long way to demonstrating the future direction of museum/community relationships as they have been explored throughout this study. 


\section{Bibliography}

Bryman, A. (2004). Social Research Methods (2nd Edition). Oxford: Oxford University Press.

Cowan, J. C. (1948). Down The Years In The Maniototo: A Survey of the Early History of Maniototo County and Naseby Borough. Dunedin: Whitcombe \& Tombs Ltd.

Denzin, N., \& Lincoln, Y. (2003). Sage Handbook of Qualitative Research. Thousand Oaks: Sage.

Dierking, L., \& Falk, J. (2000). Learning From Museums: Visitor Experiences and the Making of Meaning. Oxford: AltaMira Press.

Dierking, L., \& Falk, J. (1997). The Museum Experience. Ann Arbor: Whalesback Books.

Dierking, L., \& Pollock, W. (1998). Questioning Assumptions: An Introduction to Front-End Studies in Museums. Washington DC: Association of Science-Technology Centres.

Dodd, J., James, A., O'Riain, H., \& R, S. (2001). Small Museums and Social Inclusion. Retrieved March 16, 2006, from www.mla.gov.uk: www.mla.gov.uk/resources/assets//L/lat32_v2_pdf_5681.pdf

Guetzkow, J. (2002). How the Arts Impact Communities: An Introduction to the Literature on Arts Impact Studies. Taking the Measure of Culture Conference. Princeton University.

Hooper-Greenhill, E. (2000a). Changing Values in the Art Museum: Rethinking Communication and Learning. In B. Messias Carbonell, Museum Studies: An Anthology of Contexts (pp. 556-575). United Kingdom: Blackwell Publishing.

Hooper-Greenhill, E. (2000b). The Educational Role of the Museum. London: Routledge.

Hooper-Greenhill, E., Moussouri, T., O'Riain, H., \& Sandell, R. (2000). Museums and Social Inlcusion: The GLLAM Report. Retrieved March 17, 2006, from www.le.ac.uk/museumstudies: www.le.ac.uk/museumstudies/research/reports/GLLAM.pdf

Johnston, R. (1991). The Question of Place: Exploring the Practice of Human Geography. Oxford: Blackwell. Kreamer, C. (1992). Defining Communities Through Exhibiting and Collecting. In I. Karp, C. Kreamer, \& S. Lavine, Museums and Communities: The Politics of Public Culture (pp. 367-381). Washington DC: Smithsonian Institution Press.

Lavenda, R. (1992). Festivals and the Creation of Public Culture. In I. Karp, C. Kreamer, \& S. Lavine, Museums and Communities: The Politics of Public Culture (pp. 76-104). Washington DC: Smithsonian Institution Press.

Leinhardt, G., Crowley, K., \& Knutson, K. (2002). Learning Conversations in Museums. New Jersey: Lawrence Erlbaum Associates.

Matarasso, F. (1997). Use or Ornament: The Social Impact of Participation in the Arts. Retrieved May 7 , 2006, from www.comedia.org.uk: www.comedia.org.uk/pages/pdf/downloads/use_or_ornament.pdf McQuail, D. (1987). Mass Communication Theory (2nd Edition). London: Sage.

National Party of New Zealand. (2005). Arts \& Culture Policy. Retrieved August 18, 2005, from www.national.org.nz: www.national.org.nz

New Zealand First Party. (2005). Arts \& Culture Policy. Retrieved August 18, 2005, from www.nzfirst.org.nz: www.nzfirst.org.nz

Paasi, A. (1986). The Institutionalisation of Regions: A Theoretical Framework for Understanding the Emergence of Regions and the Constitution of Regional Identity. Fennia 164(1) , pp. 105-146. 
Perin, C. (1992). The Communicative Circle: Museums as Communities. In I. Karp, C. Kreamer, \& S. Lavine, Museums and Communities: The Politics of Public Culture (pp. 182-220). Washington DC: Smithsonian Institution Press.

Rounds, J. (1999). Meaning Making: A New Paradigm for Museum Exhibits? Exhibitionist 18(2), $5-8$. Sarantakos, S. (2005). Social Research (Third Edition). Basingstoke: Palgrave Macmillan.

Silverman, L. (1995). Visitor Meaning Making in Museums for a New Age. Curator 38(3), pp. 161-170.

Skramstad, H. (1996). Changing Public Expectations of Museums. Museums for the New Millenium. Smithsonian Institution Press.

Statistics New Zealand. (2006, November). 2006 Census Regional Summary Tables. Retrieved February 15, 2007, from www.stats.govt.nz: www.stats.govt.nz/census/2006 census data/regional_summary tables.htm

Te Papa National Services, Northland Museum Association, Ken Gorbey. (2004). Northland Museums as Attractions: A Rich Tapestry of Experiences. Retrieved March 16, 2006, from www.enterprisenorthland.co.nz: www,enterprisenorthland.co.nz/downloads/museum_strategy.pdf

The Labour Party of New Zealand. (2005). Arts \& Culture Policy. Retrieved August 18, 2005, from www.labour.org.nz: www.labour.org.nz

Unknown. (2007). aatravel.conz 101 Must Dos For Kiwis. Retrieved March 24, 2007, from AA Travel: www.aatravel.co.nz/101-must-dos-for-kiwis/

Unknown. (2006). grahamesydney.com News. Retrieved October 12, 2006, from Grahame Sydney Official Website: www.grahamesydney.com/news.asp

Wood, J. (2007). Past Vegetation and Animals of Central Otago. Central Stories Lecture Series. Alexandra. 


\section{Appendix One}

\section{Discussion Group Outline}

\section{PHASE ONE}

1. What aspects of Central Otago best define the area?

2. Which of these aspects most impacts upon your day-to-day life?

3. Do you feel there are aspects of the region that are seen as negative?

4. Where do you see Central Otago identity being displayed and showcased?

5. If Central Otago was a person, what characteristics would it have?

\section{Intermission}

\section{PHASE TWO}

1. What aspects of the Museum best represent Central Otago?

2. Are there gaps in the Museum depiction of Central Otago?

3. If the Museum was your first encounter with Central Otago, what impressions would it give you of the area?

4. Did the Museum's exhibitions remind you of your own experiences within the area?

5. If the Museum was a person, what characteristics would it have? 